\title{
Uptake, Translocation, and Consequences of Nanomaterials on Plant Growth and Stress Adaptation
}

\author{
Shahid Ali $\mathbb{D}^{1},{ }^{1}$ Asif Mehmood, ${ }^{2}$ and Naeem Khan $\mathbb{D D}^{3}$ \\ ${ }^{1}$ College of Life Sciences, Northeast Forestry University, Harbin 150040, China \\ ${ }^{2}$ Institute of Biological Sciences, Sarhad University of Science and Information Technology, Peshawar 25000, Pakistan \\ ${ }^{3}$ Department of Agronomy, Institute of Food and Agricultural Sciences, University of Florida, Gainesville, FL 32611, USA \\ Correspondence should be addressed to Shahid Ali; shahidsafi926@gmail.com and Naeem Khan; naeemkhan@ufl.edu
}

Received 21 December 2020; Revised 5 January 2021; Accepted 5 March 2021; Published 16 March 2021

Academic Editor: Bo Tan

Copyright () 2021 Shahid Ali et al. This is an open access article distributed under the Creative Commons Attribution License, which permits unrestricted use, distribution, and reproduction in any medium, provided the original work is properly cited.

\begin{abstract}
Nanotechnology has shown promising potential tools and strategies at the nanometer scale to improve food production and meet the future demands of agricultural and food security. However, considering nanotechnology's potential benefits to date, their applicability has not yet reached up to field conditions. Increasing concerns regarding absorption, translocation, bioavailability, toxicity of nanoparticles, and impropriety of the regulatory framework restrict the complete acceptance and inclination of the agricultural sector to implement nanotechnologies. The biological function of nanoparticles depends on their physicochemical properties, the method of application, and concentration. The effects of the various types of nanoparticles (NPs) on plants were determined to increase seed germination and biomass or grain yield. The NPs also increased the plant's resistance to various biotic and abiotic stresses. The plant's biological functions depend on the events that occur at the molecular level. However, little progress has been made at the molecular level influenced by nanoparticles, which is an important step in evaluating potential mechanisms and plants' effects. Therefore, it is important to understand plants' underlying mechanism and response towards nanoparticles, and the gene expression changes through molecular approaches. The associations of nanomaterials with plant cells, the process of internalization, and the distribution of biomolecules using nanoparticles as a carrier are studied but not well understood. The transmission of biomolecules, such as nucleic acids, is a major obstacle due to cell walls, limiting the application of nanomaterials in crop enhancement mediated by genetic engineering. Recently, the use of different nanomaterials for nucleic acid delivery in plant cells has been published. Here, we aim to update researchers on the absorption and translocation of nanoparticles and elaborate on the importance of nanoparticles in agriculture and crop stress tolerance.
\end{abstract}

\section{Introduction}

Significant technical advancements and innovations have been made in recent years in agriculture to meet the growing challenges of sustainable agricultural production and food security $[1,2]$. The world needs to generate $50 \%$ more food by 2050 to meet the needs of 9 billion people. This goal can only be accomplished by technical interventions to increase productivity, as land and water resources are constrained. Arable land shortage, irrigation, and reliance on conventional crops are the key concerns that have drawn the researchers' attention to using various methods. It is not surprising that attempts have been made to improve the agricultural sector using nanotechnology and nanomaterials because of nanomaterials' obvious special and incredible properties [3-5]. In particular, the use of different kinds of nanomaterials consists of metal oxides, silicates, ceramics, magnetic materials, semiconductors of quantum dots (QD), polymers, lipids, dendrimers, and emulsions [6-8]. The goals are to minimize the quantity of applied plant protection products (PPP), alleviate nutrient losses during fertilization, and maximize revenue in the agriculture sector through better nutrient management [9]. Many factors depend on the increased use of nanoparticles (NPs) in agriculture, including well-known effects, potential toxicity, monitored fate, and overdose levels. NPs can communicate with their environment, and plants are a key component of all ecosystems. Therefore, it can be concluded that NPs can communicate 
with plants and that these interactions, such as their intake and their accumulation in plant biomass, will affect their environmental fate and transport [10-12]. Nanomaterials can penetrate live plant tissues, but their aggregation in the ecosystem and their effectiveness as smart delivery systems in living plants have implications. It is important to understand whether plants can consume intact NPs and transport them to other plant tissues. NPs can enter plant tissue from either the root tissues or the above-ground tissues (e.g., cuticles, stomata, hydathodes, and trichrome) as well as through root junction and wound regions.

Nanomaterials in plant science have been reported to enhance agronomic capabilities [13-15]. NPs are used as sensing materials $[14,15]$, herbicides, pesticides, and nanofertilizers $[16,17]$, improve the plant nutrients, and act as carriers for controlled release of agrochemical [18-20]. Nanomaterials also speed up plant adaptation to various climatic changes and enhance plant tolerance [21, 22]. However, certain nanoparticles (NPs) with unique physiochemical properties naturally increase plant growth and stress resistance rather than acting as nanocarriers. The biological function of nanoparticles depends on their physicochemical properties, the application method (soil, foliar, and hydroponics), and the used concentration. Nanomaterials have also demonstrated their prominent role in plant tissue in vitro cultures, such as callus induction, organogenesis, somatic embryogenesis, and secondary metabolite production [23]. Such studies suggest that plant cells can accumulate nanoparticles through their cell walls, but the mechanism is still not well understood. Although the use of nanomaterials for DNA delivery in plant cells has also been studied in the past [24], substantial developments have been made in recent years.

This study is aimed at examining in detail the role of nanotechnology in the delivery of NPs, the use of NPs in improving seed germination, and plant growth under both natural and environmental stress conditions. In addition, we elaborate the nanotechnology's current advances and associated challenges.

\section{Absorption and Translocation of Nanoparticles}

2.1. Mechanisms of Nanoparticle Uptake by Plants. In the soil, the NPs undergo a series of bio/geotransformations, which determine the bioavailability and toxicity of NPs. The NPs translocate to aerial portions after interacting with plant roots and accumulate in cellular or subcellular organelles. Adsorption of NPs from the soil by plant roots can be described as the first step in bioaccumulation [25]. Several researchers analyzed numerous NPs and proposed that plant accumulation occurred by root adsorption accompanied by dissemination through plant tissues by certain modifications, such as crystal phase dissolution, biotransformation, and bioaccumulation. The NP's size is directly connected to the absorption of the NPs because it is a crucial parameter that enables its entrance through cell wall pores or plant stomata. Besides, size determines their subsequent transport processes into cells (i.e., plasmodesmata) or organelles of plant cells, affecting their accumulation, toxicity, and kinetics of transport into plant cells [22]. The surface area, agglomeration, and reactivity on the cell surface or within plant structures are correlated with the NP shape [26]. To determine the specific zone of interaction between plant cell structures and NPs, the NP surface is calculated by its area and morphology, which constitute essential parameters. Due to the obvious negative charge of the cell wall, the attachment of the NPs to the surface of the plant cell relies directly on the charge of the NPs. Following the charge and particle size, the hydrophobicity present on the plant surface played a crucial role in the uptake and translocation process [27]. In addition, the basic structure of nanomaterials is complementary to the evaluation of their effect on NP absorption, translocation, and aggregation in the plant [28]. The above facts demonstrate the need to standardize laboratory experiments to assess NPs in plant tissues at various levels to determine the exact effect of NPs supported by their physical-chemical properties [29]. Therefore, to understand and elucidate the absorption, translocation, and accumulation processes, a detailed study on the nature of the NPs is needed. To determine their movement and localization to various structures and cell organelles within the plant, monitoring and tracking NPs are important.

The small NPs (diameters range from 3 to $5 \mathrm{~nm}$ ) are reported to penetrate plant roots along with osmotic pressure, capillary forces, or passing directly through the root epidermal cells $[30,31]$. The epidermal cells of the root cell wall are semipermeable containing small pores and restrict the large NPs. Some NPs induced new pores in the epidermal cell wall, which facilitated its entrance $[30,31]$. After crossing the cell walls, NPs are apoplastically transported through extracellular spaces until they reach the central vascular cylinder, allowing the xylem to move unidirectionally upward. NPs, however, need to symplastically cross the Casparian strip barrier to enter the central vascular cylinder (Figure 1). This happens by binding to the endodermal cell membrane's carrier proteins through endocytosis, pore formation, and transport. NPs travel from one cell to another through the plasmodesmata as internalized in the cytoplasm [22, 32]. The NPs unable to internalize are aggregate on the Casparian strip, while the NPs that have reached to xylem are transferred to the shoots and through the phloem back to the roots $[32,33]$. NPs taken up by plants may be found within the epidermal cell wall, cortical cell cytoplasm, and nuclei [33]. NPs that are not taken up on the soil aggregate's root surface can modify the absorption of nutrients [34]. Direct absorption of NPs in seeds can occur by entering the coat via parenchymatic intercellular spaces, accompanied by diffusion in the cotyledon [22].

The NPs applied by the leaves can enter the leaves through the stomata or cuticles. The cuticle acts as a primary leaf barrier, restricting the entry of NPs to a size of $<5 \mathrm{~nm}$. The NPs $>10 \mathrm{~nm}$ enter through stomata, and their cellular transport is occurring through apoplastic and symplastic routes into the vascular system of the plant [34]. The transfer of NPs (between 10 and $50 \mathrm{~nm}$ ) is favored through the adjacent cell's cytoplasm (symplastic route). Thus, larger NPs (between 50 and $200 \mathrm{~nm}$ ) are translocated between the cells 


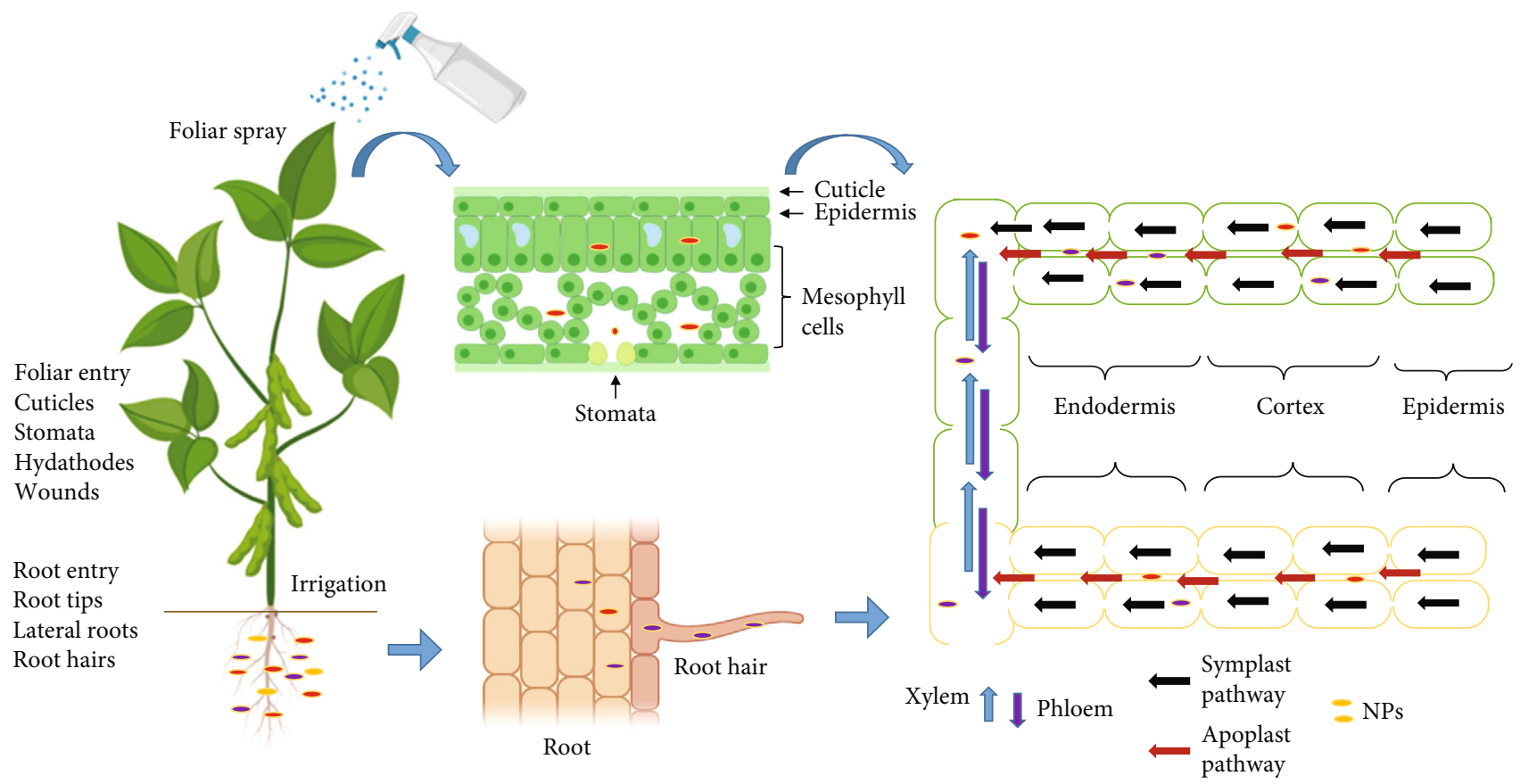

FIGURE 1: Schematic presentation of nanoparticle uptake through different routes and their translocation pathways in different plants' parts.

(apoplastic route). Internalized NPs are transported along with the sugar flow through the phloem sieve tubes. As a result of vascular transport by phloem, NPs can travel bidirectionally and accumulate in roots, stems, fruits, grains, and young leaves to varying degrees because these organs serve as potent sinks for the sap $[22,26,28,34]$. The apoplastic passage is known as a nonselective direction of least resistance. It is widely agreed that many water nutrients and nonessential metal complexes favor the apoplastic route for translocation [35]. The application methods, size, concentration, and climate are the essential factors that determined the effective adsorption of NPs after foliar application [26]. Leaf morphology and its chemical composition, the presence of trichrome, and existence of leaf exudates and waxes are essential factors that affect the trapping of NPs on the surface of the leaf [36].

It is important to introduce NPs of high purity and stability to the physiological environment. The accumulation rate of NPs by the root of plants may be impacted by environmental conditions and the properties of NPs. Previous studies reported that the application of silver sulfide (Ag2S) NPs in combination with potassium chloride and ammonium thiosulfate significantly enhanced the concentration of $\mathrm{Ag}$ NPs in the shoot and roots of Lactuca sativa. (Table 1) [37]. Soil organic matter decreased cerium dioxide $\left(\mathrm{CeO}_{2}\right)$ NPs through roots in Zea mays (Z. mays) [38].

2.2. Mechanism of Nanoparticle Translocation in Plants. Studies attempted to establish the mechanisms involved in plant structures or cell organelles in the absorption, translocation, and accumulation of various NPs [27]. The translocation and accumulation of NPs in the plant depend on the plant cells' physiology and structure, the nanomaterial interaction with the soil, and the nature and stability of the NPs
[39]. The cell wall of plants serves as a specific barrier that regulates the entrance of NPs into the cell and determines the ability to solubilize and allow the passage of NPs according to their nature $[40,41]$. The majority of studies report that the size of the cell wall's pore is the key constraint on the entrance of NPs into the plant cell. The size of NPs is $40-50 \mathrm{~nm}$ to penetrate the cell from the plant surface [42]. The nature of the NPs is a second restriction factor impacting their penetration through the cell wall and cell membrane or promoting attachment to the radical surface or radical exudates [43]. The positive charging of NPs can improve their adhesion to the cell wall. Besides, morphology and NP coating can play a significant role in their behavior on the rhizosphere and their action on plants.

The nanoparticles accumulated by plant roots translocate to different tissues in the plant's aerial part, including newly developed seeds [22]. Plant characteristics and NPs all play a crucial role in the translocation of NPs. For example, previous studies have shown that gold $(\mathrm{Au}) \mathrm{NPs}$ can accumulate in the shoot of Oryza sativa (O. sativa). In contrast, it cannot accumulate in the shoot of Cucurbita pepo and Raphanus raphanistrum [44]. Furthermore, plant roots take up the positively charged Au NPs most quickly.

In contrast, negatively charged Au NPs are translocated from the roots more resourcefully into plant shoots. Previous studies reported that titanium dioxide $\left(\mathrm{TiO}_{2}\right)$ and silicon dioxide $\left(\mathrm{SiO}_{2}\right)$ are the most stable NPs and can be found in their immaculate speciation in plant tissues $[57,58]$. NPs like copper (II) oxide $(\mathrm{CuO}), \mathrm{CeO}_{2}$, lanthanum oxide $\left(\mathrm{La}_{2} \mathrm{O}_{3}\right)$, and nickel oxide $(\mathrm{NiO})$ are capable of transformation through disparity, resulting in accumulated plant speciation changes. The transformations of zinc oxide $(\mathrm{ZnO}) \mathrm{NPs}$ were determined using synchrotron X-ray absorption (XAS) spectroscopy during exposure to different plants [59]. In Z. mays, 
TABLE 1: Accumulation of NPs in various crop tissues.

\begin{tabular}{|c|c|c|c|c|c|}
\hline \multirow{2}{*}{ NPs } & \multirow{2}{*}{ Crops } & \multirow{2}{*}{ Concentration $(\mathrm{mg} / \mathrm{L} * \mathrm{mg} / \mathrm{kg})$} & \multicolumn{2}{|c|}{ Accumulation (mg/kg) } & \multirow{2}{*}{ References } \\
\hline & & & Roots & Shoots & \\
\hline \multirow{3}{*}{ Ag-based } & O. sativa & 1000 & 20 & 5 & {$[45]$} \\
\hline & Glycine max & 4000 & 2102 & 1135 & {$[46]$} \\
\hline & Solanum lycopersicum & 250 & - & 50 & {$[47]$} \\
\hline \multirow{6}{*}{ Cu-based } & O. sativa & 1000 & 1544.1 & 17.27 & {$[48]$} \\
\hline & B. juncea & 1500 & 190.4 & - & [49] \\
\hline & Cajanus cajan & 20 & 5.82 & 19.06 & {$[50]$} \\
\hline & Vigna radiata & 125 & - & 18.46 & [51] \\
\hline & L. sativa & 250 & 3773 & - & {$[52]$} \\
\hline & Phaseolus vulgaris & 100 & 800 & - & [53] \\
\hline \multirow{2}{*}{$\mathrm{ZnO}$} & S. lycopersicum & 1000 & - & 250 & {$[54]$} \\
\hline & Z. mays & 100 & 10 & 30 & {$[55]$} \\
\hline $\mathrm{Mg}(\mathrm{OH})_{2}$ & Z. mays & 1000 & 103 & 131 & {$[56]$} \\
\hline $\mathrm{TiO}_{2}$ & S. lycopersicum & 1000 & - & 250 & {$[54]$} \\
\hline
\end{tabular}

the maximum accumulation of $\mathrm{Zn}$ occurs in the roots and shoots under the hydroponic exposure of $\mathrm{ZnO}$ NPs in various forms such as $\mathrm{Zn}$-phosphate. It may be due to increased dissolution in the rhizosphere, plant absorption, and translocation of $\mathrm{Zn}$ in the ionic form [55]. Comparable $\mathrm{Zn}$ accumulated speciation was also observed in soilgrown wheat crops $[60,61]$.

Translocation from the soil of $\mathrm{ZnO}$ and $\mathrm{CeO}_{2} \mathrm{NPs}$ into Glycine $\max \left(G\right.$. max) had been observed. The $\mathrm{CeO}_{2} \mathrm{NPs}$ were revealed to be translocated in the form of NPs, and $\mathrm{Zn}$ biotransformed into $\mathrm{Zn}$-citrus inside plant tissue [46]. The transport of $\mathrm{CuO}$ NPs from roots to shoots via xylem took place in $Z$. mays and could be further translocated from shoots back to roots via the phloem back to roots [33]. Previous studies concluded that $\mathrm{NP} \mathrm{TiO}_{2}$ plays a role in the translocation in the Triticum aestivum (T. aestivum spp.). They proposed that a threshold diameter of $140 \mathrm{~nm}$, above, cannot accumulate in the root. In addition, a threshold diameter of $36 \mathrm{~nm}$ can accumulate in the root parenchyma, could not reach the stele, and cannot be translocated into the shoot of T. aestivum [62].

\section{Mechanisms of Nanoparticle and Plant Interaction}

3.1. Effects of Nanoparticles on Plants. The NPs enter the plant system by several routes, mainly through roots and leaves. NPs interact with plants at cellular and subcellular levels after entry, promoting changes in morphological and physiological states [63]. These interactions may be positive or negative, depending on the nature of the NPs and the plant species. The chemical nature, reactivity, size, and specifically concentration of NPs in or on the plant could determine NPs' effects on plant systems [64]. The researchers used various NP application methods, such as soil application, foliar spray, or seed treatment, to examine the impact of nanoparticles on seed germination or in plant growth. Available evidence has shown that different NPs can promote seed germination [65] and plant growth and development [66-68] at concentrations below certain limits. These studies were mostly performed under artificial treatment conditions such as plate growth medium and hydrophobic or pot conditions. To understand the impact of nanoparticles on plant growth, we discuss nanoparticle's positive impact on plant seed germination and plant growth and the positive effects of NPs to improve plant stress tolerance.

3.2. Seed Germination. Germination of seeds provides a basis for the productivity, growth, and development of plants. A natural method of germination takes time, and the yield obtained is not very high indeed. But high germination has been accomplished in the case of treated seeds, making nanotechnology a potent technique for improving both germination and yield. To monitor the ability of nanoparticles to enhance germination, numerous researches have been done. The mechanism underlying the process by which NP treatments increase seed germination rates is still unclear. The NP treatments improve seed absorption and water retention; it may be attributed to increasing seed germination [69]. The tomato seeds were inoculated to media with carbon nanotubes (CNTs); after 2-day incubations, the seeds' moisture content was treated with CNTs containing $19 \%$ more than untreated seeds. These findings suggested that the CNTs promote the uptake and retention of water. The mechanism is not fully understood; maybe the CNTs create microspores [70], and water permeation channels into the seed coats [69]. It is assumed that CNTs regulate the aquaporins (AQPs) in the seed coats. The AQPs are membrane proteins and act as a water channel in the cell membrane.

Compared to the control condition, the $\mathrm{TiO}_{2}(10 \mathrm{ppm}$ concentration) on wheat displayed the lowest germination duration. In contrast, the shoot and seedling length was sufficiently higher at $2-10$ ppm nanosized $\mathrm{TiO}_{2}$ than that of the control [71]. However, higher $\mathrm{TiO}_{2}$-based NP concentrations 
had an inhibitory or no effect on wheat. Another research stated that the germination of aged spinach (Spinacia oleracea) seeds was accelerated by the nano- $\mathrm{TiO}_{2}$ treatments at proper concentrations [72]. The Cicer arietinum showed that the application of nanorod hydroxylapatite (HAP) resulted in improved germination and increased growth of the plant. The better performance relative to control and other doses was found in the presence of $1 \mathrm{mg} / \mathrm{mL}$ Hap-nanorod [73]. Soybean seeds treated with super dispersive nanocrystalline powders of cobalt, iron, and copper in a zero-valent state under laboratory conditions showed increased germination frequencies relative to control conditions [74]. Data of the germination and growth impact of Ag NPs on 11 wetland plant plants, including Eupatorium fistulosum, Panicum virgatum, Carex lurida, C. scoparia, Lolium multiflorum, C. vulpinoidea, C. crinita, Scirpus cyperinus, Phytolacca americana, Juncus effusus, and Lobelia cardinalis, belonging to six distinct families has been shown to have differential responses to different species [75]. Accelerated seed germination was shown by the treatments of singlewalled carbon nanohorns (SWCNHs) in six crop species: rice, barley, switchgrass, wheat, soybean, maize, tobacco, and tomato cell cultures [76].

3.3. Positive Impact of Nanoparticles on Plant Growth and Yield. In crop plant, the beneficial role of nanoparticles has been demonstrated: increased seed germination [77], increased shoot and root length [78], increased fruit production, improved metabolite content [79], and a substantial increase in seedling and plant vegetative biomass in many crops (Table 2). Similarly, the effect of nanoparticles has also been documented on several biochemical parameters related to plant growth and development, by increasing the nitrogen usage efficiency and enhancing the photosynthetic rate in several important crops plant, including peanuts [80], spinach [81-83], and soybeans [74]. Nanoparticles are also known for their role in improving the nutrient consumption and resistance of plants to various diseases and abiotic stresses [84]. NPs are capable of influencing plant growth and development by altering some of the physiological processes in plants. Most studies indicate that NPs can cause toxic effects above a certain concentration, and experiments based on plant toxicity evaluated their effect on the germination rate and biomass accumulation [85]. Some research has shown that NPs might also have significant effects on plants $[86,87]$.

The CNTs showed 100\% germination in Brassica juncea and Phaseolus mungo at all concentrations and displayed a large increase in root length and amount of root hairs at $20 \mathrm{ppm}$, although a slight decrease in the number of root hairs was found at a higher concentration of $40 \mathrm{ppm}$ [88]. In the seeds of Cicer arietinum, ZnO NPs improved the germination and growth rate [89]. In chickpea and mung at an optimal concentration of $\mathrm{ZnO}$ NPs, root and shoot growth improved while negative effects were observed after a certain concentration [90]. Low concentration (2 and $10 \mathrm{ppm}$ ) of $\mathrm{TiO}_{2} \mathrm{NP}$ has been shown to benefit wheat seedlings in terms of shoot lengths, higher $\mathrm{TiO}_{2} \mathrm{NP}$ concentrations have neutral effects, and $\mathrm{TiO}_{2}$ bulk has inhibitory effects [91]. At a dose of
$15 \mathrm{~kg} / \mathrm{ha}$ of silica NPs, growth parameters such as several shoots and roots, stem height, stem diameter, leaf area, and root length of maize seedlings showed significant positive effects. In comparison, $20 \mathrm{~kg} / \mathrm{ha}$ did not affect growth parameters [92]. Iron oxide (FeO) NPs are documented to promote the growth of wheat seedlings at a concentration of $100 \mathrm{ppm}$, while a high concentration of the same NPs decreased the rate of germination, root biomass, and mean time of germination [93].

Carbon dots $(1.0 \mathrm{mg} / \mathrm{mL})$ can play an important role in facilitating the growth of mung beans as they boost the beans' ability to consume and use nutrients more effectively [94]. The specific optical properties of carbon dots allow them to be transported by the vascular system through apoplastic pathways from the roots to the stems and leaves [94]. The calcium carbonate NPS accelerates growth parameters such as seed germination, root and shoot length, seedling vigor index, fresh and dry mass, and relative water content of mung (Vigna mungo) [95].

The positive effects of engineered nanomaterials (ENMs) on plants have also been identified as helping plants to consume more usable nutrients from fertilizers or soil water. For example, nano- $\mathrm{ZnO}$ in the mung bean rhizosphere has been confirmed to significantly increase the available form of $\mathrm{P}$, soil microbial population, and root volume. This may be confirmed by the increased dehydrogenase activity, which is a measure of microbial activity and soil absorption of $\mathrm{P}$ by plants. The soil-developing microbes help maintain soil quality and structure for regular nutrient biogeochemical cycling [28]. In the plant cell, nano- $\mathrm{ZnO}$ is transformed into $\mathrm{Zn}_{2}+$ ions and regulates carbonic anhydrase activity for $\mathrm{CO}_{2}$ fixation to carbohydrates. Zinc can be used as a cofactor for several enzymes, such as catalase and superoxide dismutase, to prevent oxidative damage to plant cells [28]. $\mathrm{SiO}_{2}$ also increases the activity of nitrate reductase in combination with $\mathrm{TiO}_{2}$ NPs. It acts as a key point in the reduction of nitrate $\left(\mathrm{NO}_{3}^{-}\right)$to nitrite $\left(\mathrm{NO}_{2}^{-}\right)$and improved plant absorption ability to improve fertilizer and water uptake [96]. The foliar application of $\mathrm{ZnO}$ NPs had a beneficial impact on tomato plant growth. It, therefore, opened up the question of the possible use of $\mathrm{ZnO}$ NPs as a future nanofertilizer. Likewise, foliar spray of $\mathrm{ZnO}$ NPs in pot-grown plants at $20 \mathrm{mg} \mathrm{mL}^{1}$ increases biomass production [97]. $\mathrm{TiO}_{2} \mathrm{NPs}$ have a beneficial effect on spinach growth by increasing the activity of Rubisco activase enzymes and enhancing the absorption of light or reducing the chloroplast oxidative stress caused by ultraviolet radiation during photosynthesis [98]. The anatase crystalline form of $\mathrm{TiO}_{2}$ NPs exhibits the highest catalytic activity, facilitating chlorophyll and carotene synthesis in Cucumis sativus (C. sativus) [99]. Titanium dioxide enhanced the light absorption in chlorophyll-a molecules, oxygen evolution, and electron transfer rate in spinach leaves; $\mathrm{TiO}_{2}$ NPs encourage chloroplast activity and Hill reaction [100].

The cerium (IV) oxide $\mathrm{CeO}_{2}$ NPs increased stem elongation at $1-10 \mathrm{mg} \mathrm{mL}^{-}$, and a significant improvement in fruit weight was observed at $10 \mathrm{mg} \mathrm{L}^{-1}$ [101]. Higher $\mathrm{CeO}_{2} \mathrm{NP}$ concentrations (500 $\mathrm{mg} \mathrm{kg}$ per 1) culminated in rapid shoot development with increased biomass of $31 \%$ in barley. On 
TABLE 2: The positive responses of nanomaterials on plant growth.

\begin{tabular}{|c|c|c|c|c|c|}
\hline Nanomaterials & Concentration & $\begin{array}{l}\text { Size } \\
(\mathrm{nm})\end{array}$ & Effects on plants & Crops & References \\
\hline $\mathrm{CuO}$ & $\begin{array}{l}500 \mathrm{mg} \mathrm{kg}^{-1} \\
\text { sand culture }\end{array}$ & & Increased biomass & $\begin{array}{l}\text { Triticum } \\
\text { aestivum }\end{array}$ & {$[60]$} \\
\hline $\mathrm{SiO}_{2}$ & $5 \mathrm{mM}$ & $4-10$ & Increased shoot biomass and grain weight & Oryza sativa & {$[104]$} \\
\hline SWCNT & $325,1750 \mathrm{mg} \mathrm{L}^{-1}$ & 8 & Increased the root length & $\begin{array}{l}\text { Onion and } \\
\text { cucumber }\end{array}$ & [105] \\
\hline MWCNT & $49 \mu \mathrm{g} \mathrm{mL}^{-1}$ & & Uptake nutrients ( $\mathrm{Zn}, \mathrm{Mn}, \mathrm{K}, \mathrm{Ca}$, and $\mathrm{Fe}$ ) & $\begin{array}{l}\text { Lycopersicon } \\
\text { esculentum }\end{array}$ & {$[106]$} \\
\hline $\mathrm{TiO}_{2}$ & $0.01-0.05 \%$ & $4-6$ & $\begin{array}{l}\text { Enhanced growth, increased glutamate dehydrogenase, and } \\
\text { glutamic pyruvic transaminase activity }\end{array}$ & Spinach & {$[107]$} \\
\hline $\mathrm{TiO}_{2}$ & $300-1000 \mathrm{mg} \mathrm{L}^{-1}$ & 30 & Inhibition of hydraulic conductivity & Zea mays & {$[108]$} \\
\hline $\mathrm{TiO}_{2}$ & $1000 \mathrm{mg} \mathrm{L}^{-1}$ & & Chlorophyll content & T. aestivum & {$[109]$} \\
\hline $\begin{array}{l}\text { Activated carbon- } \\
\text { based } \mathrm{TiO}_{2}\end{array}$ & $0-500 \mathrm{mg} \mathrm{L}^{-1}$ & $30-50$ & Improved germination & Tomato & [110] \\
\hline $\mathrm{ZnO}$ & $\begin{array}{l}20 \text { ppm foliar } \\
\text { spray }\end{array}$ & $1.2-6.8$ & Increased biomass & Mung bean & [111] \\
\hline
\end{tabular}

the contrary, soil supplemented with low $\mathrm{CeO}_{2}$ NP concentrations (125 and $250 \mathrm{mg} \mathrm{kg}^{1}$ ) stimulates grain production, whereas significant amounts of $\mathrm{Ce}$ are accumulated in grains and leaves. Besides, iron oxide NPs (IONPs) have been observed to increase the dry weight of soybean pods and leaves. IONPs have also been known as iron facilitators and aided in the transfer of iron photosynthate to peanut leaves, while IONPs increased root elongation in pumpkin, which is due to iron dissolution [96]. IONPs greatly encouraged tomato plant growth but caused green biomass to decrease [102]. The measurement of organic nitrogen in plant roots indicates that $51.1 \%$ of nitrogen $(\mathrm{N})$ was present in roots relative to control [103], an indicator that $\mathrm{TiO}_{2} \mathrm{NPs}$ mediate the promotion of root growth by promoting $\mathrm{N}$ accumulation.

3.4. Positive Effects of Nanoparticles on Photosynthesis. Photosynthesis is the essential mechanism that converts light energy to chemical energy for plants on earth. All living things rely on photosynthesis either directly as their energy source or indirectly as their food's ultimate energy resource. In chloroplasts, the light source of energy is converted into a chemical form using chlorophyll, $\mathrm{H}_{2} \mathrm{O}$, and $\mathrm{CO}_{2}$ as raw materials and stored in sugar molecule bonds. Several studies report that foliar application of metal NPs dramatically improves the content of chlorophyll in plants, enabling plants to synthesize more complexes for light harvesting to absorb more light energy and improve photosynthesis. $\mathrm{TiO}_{2}$ is the most studied NP because it has a photocatalytic quality and can activate an oxidation-reduction reaction, contributing to the charge transfer between light-harvesting complexes II and $\mathrm{TiO}_{2}$ NPs [112]. The effect of $\mathrm{TiO}_{2} \mathrm{NPs}$ on the photosynthetic efficiency of spinach has been reported, indicating that $\mathrm{TiO}_{2}$ NPs can increase light absorption and accelerate light energy transport and transformation. Furthermore, due to the delay in the successful photosynthetic tenure of chloroplasts, $\mathrm{TiO}_{2} \mathrm{NPs}$ will prevent chloroplasts from aging. Nanoanatase $\mathrm{TiO}_{2}$ enormously improved the electron transport chain, $\mathrm{O}_{2}$-evolving and photophosphorylation activity, and PSII photoreduction function of chlorophyll in spinach under both visible and ultraviolet (UV) radiation [113]. Also, the soluble protein and chlorophyll content of the $\mathrm{ZnO} \mathrm{NP}$-treated plants increased by $25 \%$ and $34.5 \%$, respectively, compared to those of the control [114]. Chlorophyll content increased from 62.67 to $227.42 \%$ with an aerosol-foliar spray with rising concentrations of $\mathrm{TiO}_{2} \mathrm{NPs}$ up to $500 \mathrm{mg} \mathrm{kgl}$. The transfer of $\mathrm{TiO}_{2}$ NPs in soil induces a maximum increase in chlorophyll content of $216.29 \%$ at a concentration of $750 \mathrm{mg} \mathrm{kg}^{-1}$ [54].

In $A$. thaliana, $\mathrm{TiO}_{2} \mathrm{NP}$-treated plants have 3.83 times greater light-harvesting complex II (LHCII) content as compared to the control. The $\mathrm{TiO}_{2} \mathrm{NPs}$ improve the expression of LHCII b genes which play a key role in promoting chloroplast light absorption, regulating the distribution of light energy from photosystem I (PSI) to PSII by increasing the content of LHCII and accelerating the conversion of light energy to electronic energy, water photolysis, and oxygen evolution [115]. $\mathrm{Zn}$ is an essential plant micronutrient, whereas ZnO NPs have increased the content of chlorophyll in peanuts $(1000 \mathrm{mg} / \mathrm{kg})$ [80]. Specific ZnO NP concentrations have been found to boost the qualitative and quantitative characteristics of plants and to have higher PSII fluorescence kinetics (Phi-E0, Psi-E0, and PIABS) and lower energy flux parameter values (ABC/RC, TR0/RC, DI0/RC, and ET0/RC) [116]. In an in vitro model, manganese NPs are found to be involved in enhancing the photosynthetic electron transport rate and oxygen evolution [117]. Nanoiron, either alone or in combination with nanomagnesium, has been reported to have a major impact on chlorophyll's content [118]. In addition, the single-walled carbon nanotubes (SWCNTs) increased the rate of photosynthesis three times higher than the control by penetrating and accumulating in the lipid envelope of the extracted plant and increasing the rate of electron transport via a process consistent with amplified photoabsorption [119]. 
The rate of photosynthesis was significantly increased by $\mathrm{SiO}_{2} \mathrm{NP}$ treatments due to increased activity of carbonic anhydrase and photosynthetic pigment synthesis [120]. Treatment with $\mathrm{ZnO}$ NPs for 30 minutes (at $8 \mathrm{mg} / \mathrm{L}$ ) has been reported to significantly increase the rate of photosynthesis and chlorophyll content, as well as increase the activity of carbonic anhydrase in tomato plants [121]. The increased rate of photosynthesis by nanoanatase $\mathrm{TiO}_{2}$ in spinach was found to be due to the accelerated activity of Rubisco and Rubisco activase that enabled the carboxylation of Rubisco [122] (Figure 2). Rubisco activity has also been shown to be very sensitive to Ag NPs [123]. The treatments of iron sulfide NPs have been documented to enhance the growth and yield of the plant due to the activation of the Rubisco small subunit (Rubisco $S$ ) and Rubisco large subunit (Rubisco L) genes [124].

\section{Role of Nanoparticles in Plant Stress Tolerance}

Plants can adapt or cope with unfavorable conditions such as drought, salinity, chilling, and heat stress. Plant response to such abiotic stress is extensively studied at the cellular and molecular level [125]. A transitory provocation of cytoplasmic $\mathrm{Ca}^{2+}$, ROS, abscisic acid, and increased mitogenactivated protein kinase (MAPK) pathways are included in the preliminary response of plants against abiotic stresses [126]. The advanced stage of stress response involves modulating proteins involved in cellular damage protection and regulating stress-specific gene expression.

Advances in nanomaterial engineering indicate that in existing adverse environments, nanofertilizers can improve the crop yield. In about $23 \%$ of the world's cultivated lands, salinity stress strongly limits crop production [127]. The $\mathrm{SiO}_{2}$ NPs improve germination of seeds and increase plants' fresh and dry weight and chlorophyll content with proline accumulation under $\mathrm{NaCl}$ stress in tomatoes [128, 129]. The foliar spray of iron sulfate $\left(\mathrm{FeSO}_{4}\right)$ NPs exhibits a positive response in sunflower cultivars to salinity stress tolerance. The application of iron (II) sulfate $\left(\mathrm{FeSO}_{4}\right) \mathrm{NPs}$ not only increased the leaf area, the net assimilation rate of carbon dioxide $\left(\mathrm{CO}_{2}\right)$, the chlorophyll content, the dry weight of the shoot, the substomatal concentration of $\mathrm{CO}_{2}$, the maximum photochemical efficiency of photosystem II $(\mathrm{Fv} / \mathrm{Fm})$, and the iron $(\mathrm{Fe})$ content but also decreased the significant content of sodium (Na) in the leaves [21]. Titanium dioxide $\left(\mathrm{TiO}_{2}\right)$ nanoparticles were stimulatory to the expression of antioxidant enzymes in onion seedlings, and the activity of antioxidant enzymes was further increased when $\mathrm{TiO}_{2}$ NPs were applied in combination with Ag NPs. The low $\mathrm{TiO}_{2}$ concentration increased seed germination and onion seedling growth, while the effect was reversed at the higher concentration (suppressed). In addition to superoxide dismutase, which displayed concentration-dependent increases, hydrolysis enzyme (amylase), catalase, and peroxidase activity were significantly induced, while enzyme activity was higher at lower $\mathrm{TiO}_{2}$ concentrations $(10-30 \mu \mathrm{g} / \mathrm{mL})$ and decreased at higher $\mathrm{TiO}_{2}$ concentrations (40 and $50 \mu \mathrm{g} / \mathrm{mL}$ ) [130]. The use of titanium nanoparticle foliar application on wheat to mitigate the negative impact of drought stress has also demonstrated positive results for some agronomic characteristics such as starch and gluten. The findings indicated that the application of $0.02 \% \mathrm{tiO}_{2}$ nanoparticles showed improvement in different agronomic characteristics, i.e., plant height, ear number, ear weight, number of seeds, final yield, biomass, gluten-included harvest index, and drought stress starch content [131]. Silicon can potentially be used to alleviate to some degree the effects of drought stress. Previous studies found that exposure to low sodium silicate concentrations $(1.0 \mathrm{mM})$ could moderately alleviate the adverse effects of wheat drought stress. Although the precise mechanism is unknown, silicon partially improves shoot growth, increases the content of leaf chlorophyll, and retains the capacity of leaf water in stressed plants. In addition, in wheat, it also decreases membrane lipid peroxidation [132].

It has also recently been investigated that silicon nanoparticles (SiNPs) can efficiently alleviate UV-B-induced wheat stress [22]. By controlling $\mathrm{Cd}$ accumulation, the foliar application of nano-Si at $2.5 \mathrm{mM}$ concentration greatly increases Cd stress resistance in rice plants. Nano-Si fertilizers may seem to have an advantage over conventional fertilizers in reducing the accumulation of heavy metals $[40,133]$. Despite various experiments on the stimulation of plant growth and stress resistance caused by nanomaterials, the underlying mechanisms remain largely uncovered [19]. The use of nanomaterials such as nano- $\mathrm{ZnO}$ or nano- $\mathrm{SiO}_{2}$ improves the accumulation of free proline and amino acids, the absorption of water and nutrients, and the activity of antioxidant enzymes such as catalase, glutathione reductase, nitrate reductase, superoxide dismutase, and peroxidase, which improve the plant tolerance to the extreme conditions [134] (Figure 3). Furthermore, nanomaterials affect the expression of stress-related genes. For example, the application of Ag NPs in Arabidopsis microarray analysis shows that a variety of genes that play an important role in stress tolerance have been upregulated or downregulated [135]. The upregulated genes are a large part of the response to metals and oxidative stress (cation exchanger, superoxide dismutase, peroxidase, and cytochrome P450-dependent oxidase). In comparison, downregulated genes, including systemic acquired tolerance, ethylene signaling, and auxin-regulated genes implicated in growth and organ size, are linked to the response to pathogens and hormonal stimuli [136]. In plants, certain nanomaterial-induced responses are directly involved in defense against various environmental stresses. The response of plants to nanofertilizers depends on the plant species, their growth and development stages, and the type of nanoparticles [137]. Further study is required that this technology reaches the farm gate to identify signaling pathways and regulation of gene expression by specific nanomaterials in different plant species.

Farmers have been highly dependent on pesticides to minimize crop losses, negatively affecting the environment's sustainability and human health. Recent studies have shown that nanomaterials can effectively reduce the risks of pests and diseases, thereby reducing the incidence of yield losses and environmental risks. For example, the biosynthesized Ag NPs obtained from the Gossypium hirsutum stem extract 


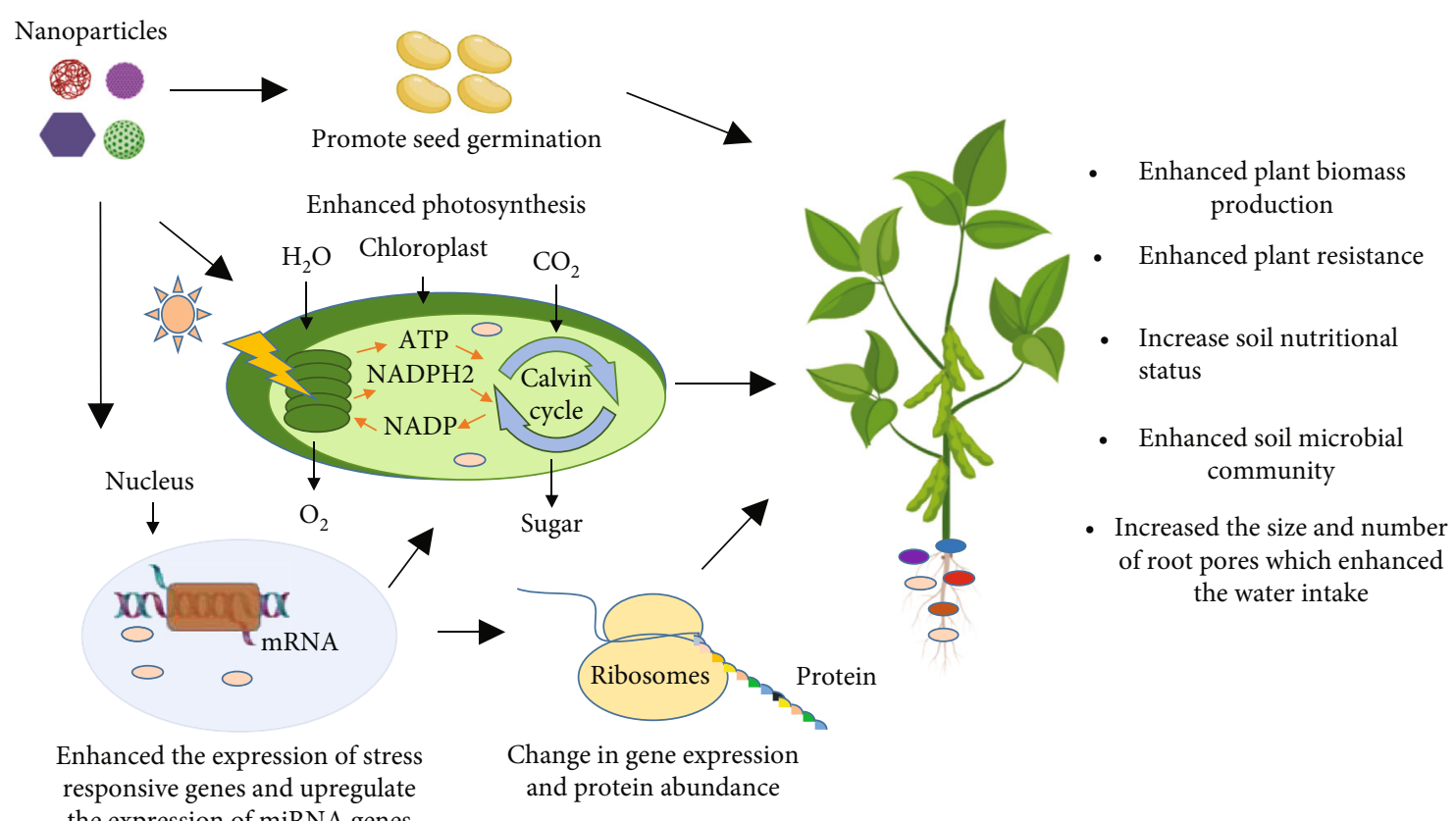

FIGURE 2: Positive effects of nanoparticles on plant growth and development. The optimum concentration of nanoparticles causes an alteration in different physiological processes to increase seed germination and photosynthesis of the plants. Further, the nanoparticles alter the gene expression of different genes and miRNAs that have a positive impact on stress tolerance and plant biomass.

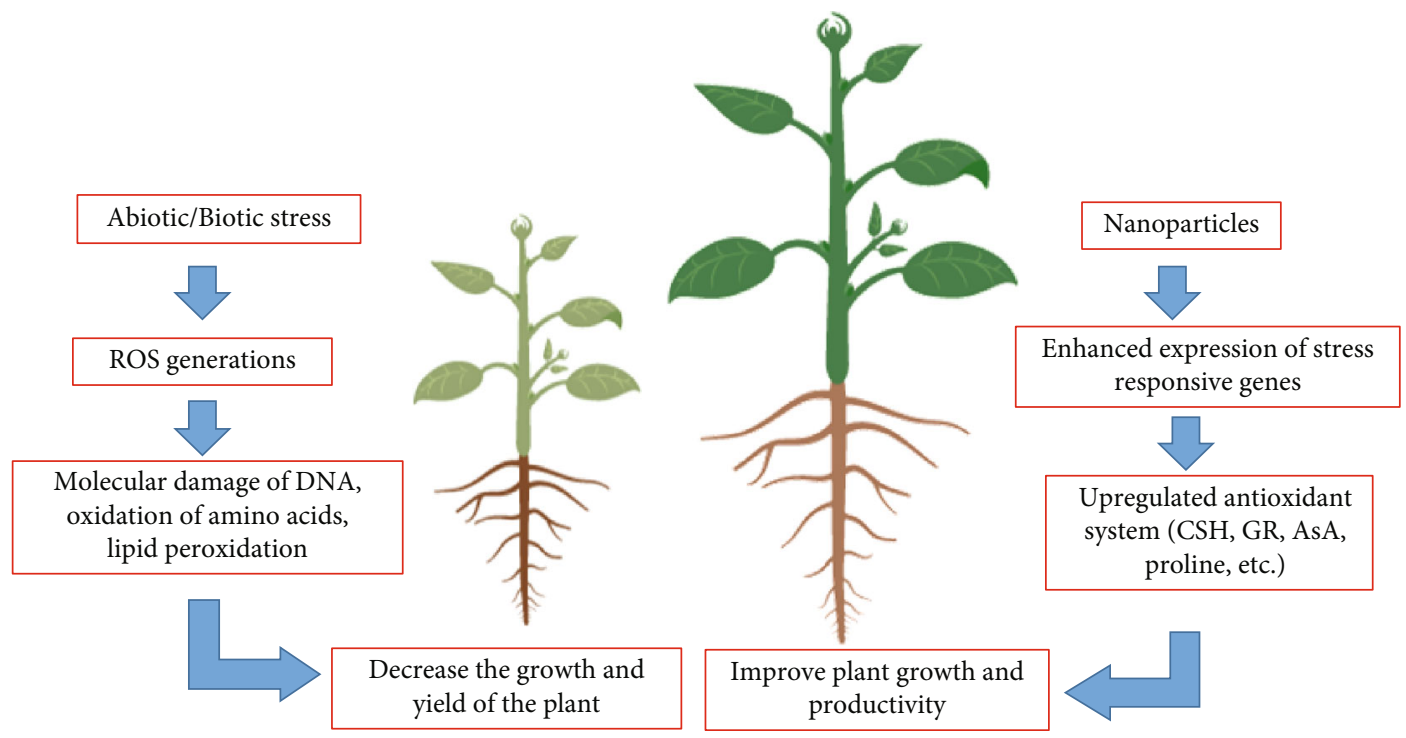

FIGURE 3: General mechanisms of nanoparticles increase the mitigating ability of plants under different stress environments.

have good antibacterial activity, as shown by the inhibition zone for Xanthomonas campestris pv. campestris and Xanthomonas axonopodis pv. malvacearum, two of the Malvaceae and Brassicaceae family's largest bacterial pathogens [138]. The metal oxides $\mathrm{ZnO}, \mathrm{CuO}$, and $\mathrm{MgO}$ could also effectively regulate many plants and soil-borne pathogen such as Alternaria alternata, Botrytis cinerea, Colletotrichum gloeosporioides, Fusarium solani, Monilinia fructicola, Fusarium oxysporum f.sp. radicis lycopersici, Ralstonia solanacearum, Verticillium Dahliae, and Phytophthora infestans in different plant species [139-142]. The use of the fungicide
Antracol with Ag-incorporated nanocomposites (Ag@CS) has improved antifungal efficacy relative to being used alone [19].

By reducing plant membrane disruption and ion leakage, $\mathrm{TiO}_{2}$ nanoparticles maintain the ability to decrease the negative impact of chilling tension. Photosynthesis is the plant system's integral process that is very sensitive to chilling stress [143]. The chilling stress damages the plant photosystem, reduces the chlorophyll content, absorption of $\mathrm{CO}_{2}$, and transpiration rate, and degrades the photosystem enzyme (Rubisco) [115]. The effect of nanoparticles on the 
photosystem has been achieved by increasing Rubisco enzyme production and chloroplast light immersion capacity [115] and inhibiting ROS production [119]. Exposure to $\mathrm{TiO}_{2}$ nanoparticles increases the expression of the Rubisco and chlorophyll-binding protein gene [144], leaf pigments, and antioxidant enzyme activities [145] and improves resistance to stress chilling. Plants suffering from cold stress upregulated the genes $\mathrm{MeAPX}_{2}$ and $\mathrm{MeCu} / \mathrm{ZnSOD}$ and increased the activities of dehydroascorbate reductase, monodehydroascorbate reductase, and glutathione reductase that scavenge ROS, resulting in repressed oxidative stress, i.e., lipid peroxidation, degradation of chlorophyll, and production of $\mathrm{H}_{2} \mathrm{O}_{2}$, eventually ensuring stress tolerance [146]. However, increased growth and biochemical physiognomies of plants exposed to cold stress have been shown by nanoparticle exposure along with chilling stress. The low concentration of selenium (Se) nanoparticles decreased the impact of heat stress by improving the chlorophyll content, hydration ability, and plant growth [147]. The low concentration of Se nanoparticles shows plant antioxidant activities, while oxidative stress is caused by the high concentration of Se nanoparticles [148]. Plants also synthesized several heat shock proteins and molecular chaperones during heat stress. Heat shock proteins help other proteins in maintaining their constancy in stress environments and are involved in heat stress tolerance [149]. Multiwall carbon nanotubes have been documented to be involved in upregulating gene expression of heat shock proteins, such as HSP90 [150].

4.1. Molecular Mechanism of Nanoparticles to Mitigate Environmental Stresses. Plants are influenced by different environmental stresses during their life cycle and thus improve their defense against environmental stress at different stages by modulating genetic, biochemical, and physiological pathways. Plants adopt molecular routes by sufficient modification of gene expressions to cope with these stresses. Several studies have shown that the induced impact of nanoparticles on plant growth and development depends on their concentration. In plants, the signaling network stimulates the defensive system, which triggers the molecular mechanism to respond to specific stress conditions. Calcium ions involved in the transduction of signals under varying stress environments act as a second messenger [151]. Sensitivity to stress signals causes the enrichment of calcium ion level in the cytosol through calcium ion channels, which is recognized by calcium ion-binding proteins that trigger alterations in gene expression as well as plant adaptation to stress conditions $[152,153]$. Nitric oxide (NO) has been shown to cause the enhancement of cytosolic calcium ions in plant cells under various biotic and abiotic stress conditions [152, 153], and thus, calcium ions persuade the synthesis of nitric oxide [154]. In O. sativa, the Ag nanoparticle treatment on roots showed that the nanoparticles were involved in responsive protein regulation and signaling of calcium ions, transcription, protein degradation, oxidative stress response pathways, cell wall synthesis, and cell division [155]. Ag nanoparticles are also documented to bind to calcium ion channels or $\mathrm{Ca}_{1} / \mathrm{Na}_{1}$ ion pumps through calcium ion receptors that influence cell metabolism. Besides, the association of C60 nanocrystals induced the functional regulation of $\mathrm{Ca}_{1} /$ calmodulin-dependent protein kinase II [156]. In addition, cadmium sulfide QDs induced overexpression of calcium-binding protein CML45 and calcium-dependent protein kinase 23 in A. thaliana. These calcium-binding proteins have been shown to regulate stress responses, and their overexpression increased plant tolerance to many abiotic stress conditions [157]. The stimulation of calcium ions by nanoparticles revealed that nanoparticles impersonate calcium ions and bind to calcium-binding proteins that activate the cascade of genes that respond to stress [158].

The exposure to zero-valent iron nanoparticles in $A$. thaliana upregulated the gene expression of $A H A 2$, which is involved in stomatal opening and enhanced the tolerance of drought [159]. In A. thaliana, the gene expression analysis of RT-PCR and the whole-genome microarrays of cDNA expression provided new insights into the molecular mechanisms of plant responses to Ag NPs [160]. Analysis of the whole-genome cDNA microarray revealed upregulation of 286 genes, including genes mainly associated with metal and oxidative stress (e.g., cytochrome P450-dependent oxidase, vacuolar cation/proton exchanger, peroxidase superoxide, and dismutase), and downregulation of 81 genes, including plant defense and hormone stimulus genes [155]. In A. thaliana, the effect of zinc oxide ( $\mathrm{ZnO})$ [161], fullerene soot (FS), or titanium dioxide $\left(\mathrm{nTiO}_{2}\right)$ nanoparticles on root gene expression showed 660 up- and 826 downregulated genes, 232 up- and 189 downregulated genes, and 80 upand 74 downregulated genes, respectively (translation gap $>2$-fold). The $\mathrm{ZnO}$ and FS mediated genes predominantly ontological groups annotated as stress responsive, including abiotic responsive genes such as drought and salinity as well as biotic genes including pathogen defense and wounding stimuli [69].

The miRNAs have been involved in the control of plant and animal biological processes and play an important role in plant responses to abiotic and biotic stresses [162]. In $A$. thaliana and $N$. tabacum, the microRNA (miRNA) gene expression was analyzed. The microRNAs are small noncoding RNAs (22-24 nucleotides), which regulate the posttranscriptional gene expression by inhibiting mRNA translation to peptides or degrading mRNA [163]. The miRNAs have been reported to mediate the stress-responsive gene expression during salt and water stress by modifying gene expression. In a tobacco cell, the nanotube stimulates the growth and gene expression [164]. It has been reported that miRNA genes are upregulated and played an important role under $\mathrm{Al}_{2} \mathrm{O}_{3}$ NP stress. With increasing concentrations of $\mathrm{Al}_{2} \mathrm{O}_{3}$ NPs, the expression of nine miRNAs (miR159, miR162, miR167, miR169, miR395, miR396, miR397, miR398, and miR399) was significantly upregulated $[162,163]$.

\section{Nanomaterials for Genetic Engineering}

Climate change and an increasing world population and genetic modification of plants have improved crop production by conferring desirable genetic traits to crops. The plant cell walls act as a barrier in the delivery of exogenous molecules into plant cells. Various strategies based on 

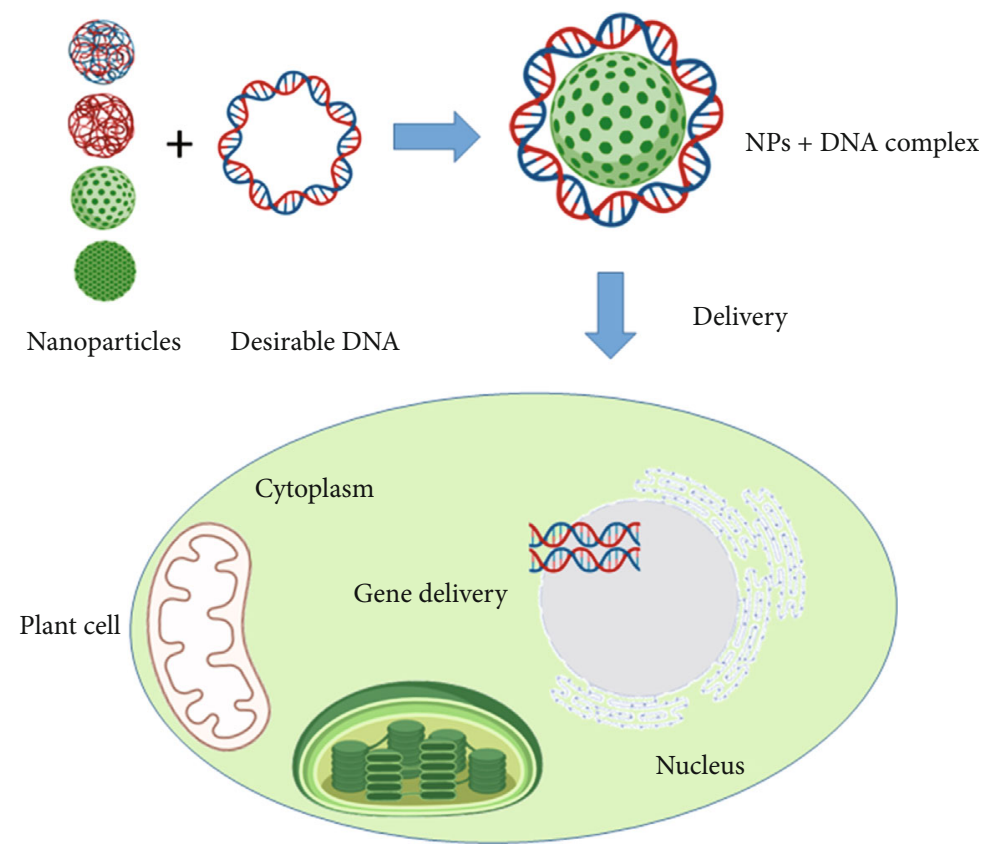

FIGURE 4: Graphical presentation of nanomaterials acting as a substitute of conventional gene delivery systems for plant genetic engineering.

Agrobacterium transformation or biolistic approaches are used worldwide for DNA transmission in plant cells to conquer this challenge and achieve plant genetic transformation. Limitations to these techniques are based on limited host range and extensive damage to plants, often preventing the plant development. Genetic engineering, although there is advancement in plants, has lagged and recently seen significant advancements. There are relatively fewer plants than the various and complex gene and protein distribution methods developed for animal systems. In general, modern plant genetic transformation requires two main steps: the distribution of genetic delivery and regeneration of the transformed plant, the requirement and complexity of the latter being strongly dependent on what method of delivery is used and how much the transformation is stable. There are three components of regeneration procedures: the induction of competent totipotent tissue, callus-forming tissue culture, and selection and progeny segregation.

Several of the pioneering experiments in nanomaterialbased plant genetic engineering have been carried out in plant cell cultures. Nanoparticles are attractive materials for biomolecule transmission due to their ability to penetrate plant cell walls without external force, wide host range applicability, and highly tunable physicochemical properties.

For instance, a good approach to delivering DNA in different calli (maize, soybean, tobacco, rice, and cotton) has been documented as silicon carbide-mediated transformation [165, 166]. Although lagging behind the progress made in animal systems, findings recently published in plants suggest that NMs can transcend the cell wall barrier in adult plants and reduce the limitations of current transgene delivery systems. One seminal study showed that dsRNA of various plant viruses could be loaded on nontoxic, degradable, layered double hydroxide $(\mathrm{LDH})$ clay nanoparticles or
BioClay. The dsRNAs and/or their RNA breakdown products offer protection in sprayed tobacco leaves against the Cauliflower Mosaic Virus (CMV), but they also confer systemic protection of the viral challenge to newly emerged, unsprayed leaves 20 days after a single tobacco spray procedure [167]. An effective, stable genetic transformation via magnetic nanoparticles (MNPs) has been achieved in cotton plants. The $\beta$-glucuronidase (GUS) reporter gene-MNP complex has been magnetically infiltrated into cotton pollen grains without affecting the pollen's viability. Cotton transgenic plants were successfully produced by pollination with magnetofected pollen, and exogenous DNA was successfully incorporated into the genome, effectively expressed, and stably inherited in the self-acquired offspring [168]. The scaffolds of carbon nanotubes applied by infusion to external plant tissue were used to transfer linear and plasmid DNA and siRNA into E. sativa protoplasts and T. aestivum, Gossypium hirsutum, Eruca sativa, and Nicotiana benthamiana leaves resulting in a high transient expression of Green Fluorescent Protein (GFP). The small interfering RNA (siRNA) was additionally supplied to $N$. Benthamiana plants that constitutively expressed GFP, allowing the gene to be silenced by $95 \%$ [169]. The first and most promising approach to mesoporous silica nanoparticle- (MSN-) mediated genome editing has recently been proposed. MSNs are used as carriers in Zea mays immature embryos to transport Cre recombinase, carrying loxP sites incorporated into chromosomal DNA. The loxP was correctly recombined after the biolistic application of engineered MSNs in plant tissues, establishing an effective genome editing [170]. As such, NPbased biomolecule delivery to plants is designed to allow DNA, single guide RNA (sgRNA), and RNP delivery for higher-throughput plant genome editing (Figure 4). Thus, it warrants a discussion on the state of the plant genome editing field. 


\section{Conclusion and Perspectives}

In recent years, nanotechnology research has suggested the development of NPs as a powerful technique to reduce existing problems resulting from conventional fertilizers in traditional agricultural systems. The results relating to nutritional elements containing NPs (i.e., $\mathrm{Fe}, \mathrm{Cu}, \mathrm{Se}$, and $\mathrm{Co}$ ) have shown substantial scientific evidence of their efficacy in improving the micronutrients of the plant, which has been reflected by improved growth parameters and significant improvements at the physiological level (i.e., chlorophyll and carotenoids, photosynthetic activity, metabolic pathways, and transpiration rate). A major obstacle is the precise dosage and activity of NPs on the surface of plant targets, so minimizing the leakage of chemical products extracted from bulk materials (i.e., mineral fertilizers) has become a valuable feature that facilitates the future use of NPs. However, critical studies carried out under controlled conditions are desperately required to determine the role of NPs in and out of the plant and their effects on the environment. The basic dosage of NPs, exposure duration, translocation and accumulation, and mechanism of action on plants are important for an application strategy to be developed. In addition, the secondary effects and accumulation of soil, air, water, and biotic organisms in the ecosystem are critical in deciding the exact impacts of NPs and their effects on the ecosystem.

\section{Data Availability}

All data generated or analyzed during this study are included in this published article.

\section{Conflicts of Interest}

The authors declare no conflict of interest.

\section{References}

[1] S. Dwivedi, Q. Saquib, A. A. Al-Khedhairy, and J. Musarrat, "Understanding the role of nanomaterials in agriculture," in Microbial Inoculants in Sustainable Agricultural Productivity, D. P. Singh, H. B. Singh, and R. Prabha, Eds., pp. 271-288, Springer, New Delhi, India, 2016.

[2] T. J. Kou, W. W. Yu, S. K. Lam, D. L. Chen, Y. P. Hou, and Z. Y. Li, "Differential root responses in two cultivars of winter wheat (Triticum aestivum L.) to elevated ozone concentration under fully open-air field conditions," Journal of Agronomy and Crop Science, vol. 204, pp. 325-332, 2018.

[3] R. Grillo, A. H. Rosa, and L. F. Fraceto, "Engineered nanoparticles and organic matter: a review of the state-of-the-art," Chemosphere, vol. 119, pp. 608-619, 2015.

[4] C. E. Handford, M. Dean, M. Henchion, M. Spence, C. T. Elliott, and K. Campbell, "Implications of nanotechnology for the agri-food industry: opportunities, benefits and risks," Trends in Food Science \& Technology, vol. 40, no. 2, pp. 226-241, 2014.

[5] A. Husen and K. S. Siddiqi, "Phytosynthesis of nanoparticles: concept, controversy and application," Nanoscale Research Letters, vol. 9, no. 1, p. 229, 2014.
[6] C. Parisi, M. Vigani, and E. Rodríguez-Cerezo, "Agricultural nanotechnologies: what are the current possibilities?," Nano Today, vol. 10, no. 2, pp. 124-127, 2015.

[7] Y. Bhagat, K. Gangadhara, C. Rabinal, G. Chaudhari, and P. Ugale, "Nanotechnology in agriculture: a review," Journal of Pure and Applied Microbiology, vol. 9, pp. 737747, 2015.

[8] P. S. Bindraban, C. Dimkpa, L. Nagarajan, A. Roy, and R. Rabbinge, "Revisiting fertilisers and fertilisation strategies for improved nutrient uptake by plants," Biology and Fertility of Soils, vol. 51, no. 8, pp. 897-911, 2015.

[9] A. Servin, W. Elmer, A. Mukherjee et al., "A review of the use of engineered nanomaterials to suppress plant disease and enhance crop yield," Journal of Nanoparticle Research, vol. 17, pp. 1-21, 2015.

[10] K. Jeyasubramanian, U. U. G. Thoppey, G. S. Hikku, N. Selvakumar, A. Subramania, and K. Krishnamoorthy, "Enhancement in growth rate and productivity of spinach grown in hydroponics with iron oxide nanoparticles," RSC Advances, vol. 6, no. 19, pp. 15451-15459, 2016.

[11] N. Khan and A. Bano, "Role of plant growth promoting rhizobacteria and Ag-nano particle in the bioremediation of heavy metals and maize growth under municipal wastewater irrigation," International Journal of Phytoremediation, vol. 18, no. 3, pp. 211-221, 2015.

[12] F. Mirzajani, H. Askari, S. Hamzelou, M. Farzaneh, and A. Ghassempour, "Effect of silver nanoparticles on Oryza sativa L. and its rhizosphere bacteria," Ecotoxicology and environmental safety, vol. 88, pp. 48-54, 2013.

[13] M. L. Verma, P. Kumar, D. Sharma, A. D. Verma, and A. K. Jana, "Advances in nanobiotechnology with special reference to plant systems," in Plant Nanobionics, pp. 371-387, Springer, Cham, 2019.

[14] S. Chaudhary, A. Umar, K. K. Bhasin, and S. Baskoutas, "Chemical sensing applications of $\mathrm{ZnO}$ nanomaterials," Materials, vol. 11, no. 2, p. 287, 2018.

[15] J. S. Duhan, R. Kumar, N. Kumar, P. Kaur, K. Nehra, and S. Duhan, "Nanotechnology: the new perspective in precision agriculture," Biotechnology Reports, vol. 15, pp. 1123, 2017.

[16] D. R. MC, C. Monreal, M. Schnitzer, R. Walsh, and Y. Sultan, "Nanotechnology in fertilizers," Nature Nanotechnology, vol. 5, no. 2, pp. 91-91, 2010.

[17] R. Liu and R. Lal, "Potentials of engineered nanoparticles as fertilizers for increasing agronomic productions," Science of the Total Environment, vol. 514, pp. 131-139, 2015.

[18] G. Medina-Pérez, F. Fernández-Luqueño, R. G. CamposMontiel, K. B. Sánchez-López, L. N. Afanador-Barajas, and L. Prince, "Nanotechnology in crop protection: Status and future trends," in Nano-Biopesticides Today and Future Perspectives, pp. 17-45, Acaemic Press, 2019.

[19] Y. Shang, M. Hasan, G. J. Ahammed, M. Li, H. Yin, and J. Zhou, "Applications of nanotechnology in plant growth and crop protection: a review," Molecules, vol. 24, no. 14, p. 2558, 2019.

[20] J. Lv, P. Christie, and S. Zhang, "Uptake, translocation, and transformation of metal-based nanoparticles in plants: recent advances and methodological challenges," Environmental Science: Nano, vol. 6, pp. 41-59, 2019.

[21] S. Torabian, S. Farhangi-Abriz, and M. Zahedi, "Efficacy of FeSO 4 nano formulations on osmolytes and antioxidative 
enzymes of sunflower under salt stress," Indian Journal of Plant Physiology, vol. 23, no. 2, pp. 305-315, 2018.

[22] D. K. Tripathi, S. Singh, V. P. Singh, S. M. Prasad, N. K. Dubey, and D. K. Chauhan, "Silicon nanoparticles more effectively alleviated UV-B stress than silicon in wheat (Triticum aestivum) seedlings," Plant Physiology and Biochemistry, vol. 110, pp. 70-81, 2017.

[23] D. H. Kim, J. Gopal, and I. Sivanesan, "Nanomaterials in plant tissue culture: the disclosed and undisclosed," RSC Advances, vol. 7, pp. 36492-36505, 2017.

[24] O. Serik, I. Ainur, K. Murat, M. Tetsuo, and I. Masaki, "Silicon carbide fiber-mediated DNA delivery into cells of wheat (Triticum acstivum L.) mature embryos," Plant Cell Reports, vol. 16, no. 3-4, pp. 133-136, 1996.

[25] R. Nair, S. H. Varghese, B. G. Nair, T. Maekawa, Y. Yoshida, and D. S. Kumar, "Nanoparticulate material delivery to plants," Plant Science, vol. 179, no. 3, pp. 154-163, 2010.

[26] W. N. Wang, J. C. Tarafdar, and P. Biswas, "Nanoparticle synthesis and delivery by an aerosol route for watermelon plant foliar uptake," Journal of Nanoparticle Research, vol. 15, no. 1, p. 1417, 2013.

[27] A. Kaphle, P. N. Navya, A. Umapathi, and H. K. Daima, "Nanomaterials for agriculture, food and environment: applications, toxicity and regulation," Environmental Chemistry Letters, vol. 16, no. 1, pp. 43-58, 2018.

[28] R. Raliya, C. Franke, S. Chavalmane, R. Nair, N. Reed, and P. Biswas, "Quantitative understanding of nanoparticle uptake in watermelon plants," Frontiers in Plant Science, vol. 7, p. 1228, 2016.

[29] Z. Zhang, F. Kong, B. Vardhanabhuti, A. Mustapha, and M. Lin, "Detection of engineered silver nanoparticle contamination in pears," Journal of Agricultural and Food Chemistry, vol. 60, pp. 10762-10767, 2012.

[30] D. Lin and B. Xing, "Root uptake and phytotoxicity of $\mathrm{ZnO}$ nanoparticles," Environmental Science \& Technology, vol. 42, pp. 5580-5585, 2008.

[31] W. Du, Y. Sun, R. Ji, J. Zhu, J. Wu, and H. Guo, “TiO2 and $\mathrm{ZnO}$ nanoparticles negatively affect wheat growth and soil enzyme activities in agricultural soil," Journal of Environmental Monitoring, vol. 13, no. 4, pp. 822-828, 2011.

[32] A. Perez-de-Luque, "Interaction of nanomaterials with plants: what do we need for real applications in agriculture?," Frontiers in Environmental Science, vol. 5, p. 12, 2017.

[33] Z. Wang, X. Xie, J. Zhao et al., "Xylem-and phloem-based transport of $\mathrm{CuO}$ nanoparticles in maize (Zea mays L.)," Environmental science \& technology, vol. 46, no. 8, pp. 4434-4441, 2012.

[34] B. Ruttkay-Nedecky, O. Krystofova, L. Nejdl, and V. Adam, "Nanoparticles based on essential metals and their phytotoxicity," Journal of Nanbiotechnology, vol. 15, no. 1, p. 33, 2017.

[35] S. M. Banijamali, M. Feizian, A. Alinejadian Bidabadi, and E. Mehdipour, "Evaluation uptake and translocation of iron oxide nanoparticles and its effect on photosynthetic pigmentation of chrysanthemum," Journal of Ornamental Plants, vol. 9, no. 4, 2019.

[36] C. Larue, H. Castillo-Michel, S. Sobanska et al., "Foliar exposure of the crop Lactuca sativa to silver nanoparticles: evidence for internalization and changes in Ag speciation," Journal of Hazardous Materials, vol. 264, pp. 98-106, 2014.

[37] C. L. Doolette, M. J. McLaughlin, J. K. Kirby, and D. A. Navarro, "Bioavailability of silver and silver sulfide nanopar- ticles to lettuce (Lactuca sativa): effect of agricultural amendments on plant uptake," Journal of Hazardous Materials, vol. 300, pp. 788-795, 2015.

[38] L. Zhao, J. R. Peralta-Videa, A. Varela-Ramirez et al., "Effect of surface coating and organic matter on the uptake of $\mathrm{CeO} 2$ NPs by corn plants grown in soil: insight into the uptake mechanism," Journal of Hazardous Materials, vol. 225, pp. 131-138, 2012.

[39] M. Janmohammadi, T. Amanzadeh, N. Sabaghnia, and V. Ion, "Effect of nano-silicon foliar application on safflower growth under organic and inorganic fertilizer regimes," Botanica, vol. 22, pp. 53-64, 2016.

[40] N. Khan and A. Bano, "Modulation of phytoremediation and plant growth by the treatment with PGPR, Ag nanoparticle and untreated municipal wastewater," International journal of phytoremediation, vol. 18, no. 12, pp. 1258-1269, 2016.

[41] I. S. Naruka, K. D. Gujar, and L. Gopal, "Effect of foliar application of zinc and molybdenum on growth and yield of okra (Abelmoschus esculentus L. Moench) cv. Pusa Sawani," Haryana Journal of Horticultural Sciences, vol. 29, no. 3/4, pp. 266-267, 2000.

[42] S. R. Mousavi, M. Galavi, and G. Ahmadvand, "Effect of zinc and manganese foliar application on yield, quality and enrichment on potato (Solanum tuberosum L.)," Asian Journal of Plant Sciences, vol. 6, no. 8, pp. 1256-1260, 2007.

[43] F. Ling and M. Silberbush, "Response of maize to foliar vs. soil application of nitrogen-phosphorus-potassium fertilizers," Journal of plant nutrition, vol. 25, no. 11, pp. 23332342, 2002.

[44] Z. J. Zhu, H. Wang, B. Yan et al., "Effect of surface charge on the uptake and distribution of gold nanoparticles in four plant species," Environmental Science \& Technology, vol. 46, no. 22, pp. 12391-12398, 2012.

[45] P. Thuesombat, S. Hannongbua, S. Akasit, and S. Chadchawan, "Effect of silver nanoparticles on rice (Oryza sativa L. cv. KDML 105) seed germination and seedling growth," Ecotoxicology and Environmental Safety, vol. 104, pp. 302-309, 2014.

[46] J. A. Hernandez-Viezcas, H. Castillo-Michel, J. C. Andrews et al., "In situ synchrotron X-ray fluorescence mapping and speciation of $\mathrm{CeO} 2$ and $\mathrm{ZnO}$ nanoparticles in soil cultivated soybean (Glycine max)," ACS Nano, vol. 7, pp. 1415-1423, 2013.

[47] I. O. Adisa, S. Rawat, V. L. R. Pullagurala et al., "Nutritional status of tomato (Solanum lycopersicum) fruit grown in Fusarium-infested soil: impact of cerium oxide nanoparticles," Journal of Agricultural and Food Chemistry, vol. 68, no. 7, pp. 1986-1997, 2020.

[48] M. V. J. Da Costa and P. K. Sharma, "Effect of copper oxide nanoparticles on growth, morphology, photosynthesis, and antioxidant response in Oryza sativa," Photosynthetica, vol. 54, no. 1, pp. 110-119, 2016.

[49] S. Rao and G. S. Shekhawat, "Phytotoxicity and oxidative stress perspective of two selected nanoparticles in Brassica juncea," 3 Biotech, vol. 3, no. 6, p. 244, 2016.

[50] S. Shende, D. Rathod, A. Gade, and M. Rai, "Biogenic copper nanoparticles promote the growth of pigeon pea (Cajanus cajan L.)," IET Nanobiotechnology, vol. 11, pp. 773-781, 2017.

[51] P. S. Jahagirdar, P. K. Gupta, S. P. Kulkarni, and P. V. Devarajan, "Polymeric curcumin nanoparticles by a facile in situ method for macrophage targeted delivery," Bioengineering \& Translational Medicine, vol. 4, no. 1, pp. 141-151, 2019. 
[52] T. Xiong, C. Dumat, V. Dappe et al., "Copper oxide nanoparticle foliar uptake, phytotoxicity, and consequences for sustainable urban agriculture," Environmental Science \& Technology, vol. 51, pp. 5242-5251, 2017.

[53] S. A. Apodaca, W. Tan, O. E. Dominguez, J. A. HernandezViezcas, J. R. Peralta-Videa, and J. L. Gardea-Torresdey, "Physiological and biochemical effects of nanoparticulate copper, bulk copper, copper chloride, and kinetin in kidney bean (Phaseolus vulgaris) plants," Science of the Total Environment, vol. 599, pp. 2085-2094, 2017.

[54] R. Raliya, R. Nair, S. Chavalmane, W. N. Wang, and P. Biswas, "Mechanistic evaluation of translocation and physiological impact of titanium dioxide and zinc oxide nanoparticles on the tomato (Solanum lycopersicum L.) plant," Metallomics, vol. 7, pp. 1584-1594, 2015.

[55] J. Lv, S. Zhang, L. Luo, J. Zhang, K. Yang, and P. Christied, "Accumulation, speciation and uptake pathway of $\mathrm{ZnO}$ nanoparticles in maize," Environmental Science. Nano, vol. 2, pp. 68-77, 2015.

[56] S. Shinde, P. Paralikar, A. P. Ingle, and M. Rai, "Promotion of seed germination and seedling growth of Zea mays by magnesium hydroxide nanoparticles synthesized by the filtrate from Aspergillus niger," Arabian Journal of Chemistry, vol. 13, no. 1, pp. 3172-3182, 2020.

[57] C. Larue, H. Khodja, N. Herlin-Boime et al., "Investigation of titanium dioxide nanoparticles toxicity and uptake by plants," Journal of Physics: Conference Series, vol. 304, p. 12057, 2011.

[58] A. D. Servin, H. Castillo-Michel, J. A. Hernandez-Viezcas, B. C. Diaz, J. R. Peralta-Videa, and J. L. Gardea-Torresdey, "Synchrotron micro-XRF and micro-XANES confirmation of the uptake and translocation of $\mathrm{TiO} 2$ nanoparticles in cucumber (Cucumis sativus) plants," Environmental Science \& Technology, vol. 46, no. 14, pp. 7637-7643, 2012.

[59] H. A. Castillo-Michel, C. Larue, A. E. Pradas del Real, M. Cotte, and G. Sarret, "Practical review on the use of synchrotron based micro- and nano-X-ray fluorescence mapping and X-ray absorption spectroscopy to investigate the interactions between plants and engineered nanomaterials," Plant Physiology and Biochemistry, vol. 110, pp. 13-32, 2017.

[60] C. O. Dimkpa, J. E. McLean, D. E. Latta et al., "CuO and $\mathrm{ZnO}$ nanoparticles: phytotoxicity, metal speciation, and induction of oxidative stress in sand-grown wheat," Journal of Nanoparticle Research, vol. 14, pp. 1-15, 2012.

[61] C. O. Dimkpa, D. E. Latta, J. E. McLean, D. W. Britt, M. I. Boyanov, and A. J. Anderson, "Fate of $\mathrm{CuO}$ and $\mathrm{ZnO}$ nanoand microparticles in the plant environment," Environmental Science \& Technology, vol. 47, no. 9, pp. 4734-4742, 2013.

[62] C. Larue, J. Laurette, N. Herlin-Boime et al., "Accumulation, translocation and impact of $\mathrm{TiO} 2$ nanoparticles in wheat (Triticum aestivum spp.): influence of diameter and crystal phase," Science of the Total Environment, vol. 431, pp. 197208, 2012.

[63] M. R. Khan, V. Adam, T. F. Rizvi et al., "Nanoparticle-plant interactions: two-way traffic," Small, vol. 15, no. 37, p. 1901794, 2019.

[64] Y. Ma, L. Kuang, X. He et al., "Effects of rare earth oxide nanoparticles on root elongation of plants," Chemosphere, vol. 78, no. 3, pp. 273-279, 2010.

[65] M. Hatami, "Stimulatory and inhibitory effects of nanoparticulates on seed germination and seedling vigor indices," in
Nanoscience and Plant-Soil Systems, pp. 357-385, Springer, Cham, 2017.

[66] F. Aslani, S. Bagheri, N. Muhd Julkapli, A. S. Juraimi, F. S. G. Hashemi, and A. Baghdadi, "Effects of engineered nanomaterials on plants growth: an overview," The Scientific World Journal, vol. 2014, 28 pages, 2014.

[67] M. C. Pallavi, R. Srivastava, S. Arora, and A. K. Sharma, "Impact assessment of silver nanoparticles on plant growth and soil bacterial diversity," 3 Biotech, vol. 6, no. 2, p. 254, 2016.

[68] R. Nair, "Effects of nanoparticles on plant growth and development," in Plant nanotechnology, C. Kole, D. Kumar, and M. Khodakovskaya, Eds., pp. 95-118, Springer, Cham, 2016.

[69] M. Khodakovskaya, E. Dervishi, M. Mahmood et al., "Carbon nanotubes are able to penetrate plant seed coat and dramatically affect seed germination and plant growth," American Chemical Society Nano, vol. 3, pp. 3221-3227, 2009.

[70] J. R. Sanborn, X. Chen, Y. C. Yao et al., "Carbon nanotube porins in amphiphilic block copolymers as fully synthetic mimics of biological membranes," Advanced Materials, vol. 30, article e1803355, 2018.

[71] H. Feizi, P. R. Moghaddam, N. Shahtahmassebi, and A. Fotovat, "Impact of bulk and nanosized titanium dioxide (TiO2) on wheat seed germination and seedling growth," Biological Trace Element Research, vol. 146, no. 1, pp. 101-106, 2012.

[72] L. Zheng, F. Hong, S. Lu, and C. Liu, "Effect of nano- $\mathrm{TiO}_{2}$ on strength of naturally aged seeds and growth of spinach," Biological Trace Element Research, vol. 104, no. 1, pp. 083-092, 2005.

[73] N. Bala, A. Dey, S. Das, R. Basu, and P. Nandy, "Effect of hydroxyapatite nanorod on chickpea (Cicer arietinum) plant growth and its possible use as nano-fertilizer," Iranian Journal of Plant Physiology, vol. 4, no. 3, pp. 1061-1069, 2014.

[74] Q. B. Ngo, T. H. Dao, H. C. Nguyen, T. V. TranXT Nguyen, T. D. Khuu, and T. H. Huynh, "Effects of nanocrystalline powders $(\mathrm{Fe}, \mathrm{Co}$ and $\mathrm{Cu})$ on the germination, growth, crop yield and product quality of soybean (Vietnamese species DT-51)," Advances in Natural Sciences: Nanoscience and Nanotechnology, vol. 5, pp. 1-7, 2014.

[75] L. Yin, B. P. Colman, B. M. McGill, J. P. Wright, and E. S. Bernhardt, "Effects of silver nanoparticle exposure on germination and early growth of eleven wetland plants," PLoS One, vol. 7, no. 10, article e47674, 2012.

[76] A. Milewska-Hendel, R. Gawecki, M. Zubko, D. Stróż, and E. Kurczynska, "Diverse influence of nanoparticles on plant growth with a particular emphasis on crop plants," Acta Agrobotanica, vol. 69, no. 4, 2016.

[77] K. Gopinath, S. Gowri, V. Karthika, and A. Arumugam, "Green synthesis of gold nanoparticles from fruit extract of Terminalia arjuna, for the enhanced seed germination activity of Gloriosa superba," Journal of Nanostructure in Chemistry, vol. 4, no. 3, p. 115, 2014.

[78] A. Hafeez, A. Razzaq, T. Mahmood, and H. M. Jhanzab, "Potential of copper nanoparticles to increase growth and yield of wheat," Journal of Nanoscience with Advanced Technology, vol. 1, no. 1, pp. 6-11, 2015.

[79] C. Kole, P. Kole, K. M. Randunu, P. Choudhary, R. Podila, and P. C. Ke, "Nanobiotechnology can boost crop production and quality: first evidence from increased plant biomass, fruit yield and phytomedicine content in bitter melon 
(Momordica charantia)," BMC Biotechnology, vol. 13, no. 1, p. 37, 2013.

[80] T. N. V. K. V. Prasad, P. Sudhakar, Y. Sreenivasulu et al., "Effect of nanoscale zinc oxide particles on the germination, growth and yield of peanut," Journal of Plant Nutrition, vol. 35, pp. 905-927, 2012.

[81] F. Gao, F. Hong, C. Liu et al., "Mechanism of nanoanatase $\mathrm{TiO} 2$ on promoting photosynthetic carbon reaction of spinach," Biological trace element research, vol. 111, pp. 239-253, 2008.

[82] S. J. Klaine, P. J. J. Alvarez, G. E. Batley et al., "Nanomaterials in the environment: behavior, fate bioavailability, and effects," Environmental Toxicology and Chemistry, vol. 27, pp. 1825-1851, 2008.

[83] M. Linglan, L. Chao, Q. Chunxiang et al., "Rubisco activase mRNA expression in spinach: modulation by nanoanatase treatment," Biological Trace Element Research, vol. 122, no. 2, pp. 168-178, 2008.

[84] P. Wang, E. Lombi, F. J. Zhao, and P. M. Kopittke, "Nanotechnology: a new opportunity in plant sciences," Trends in Plant Science, vol. 21, no. 8, pp. 699-712, 2016.

[85] B. Aken Van, "Gene expression changes in plants and microorganisms exposed to nanomaterials," Current Opinion in Biotechnology, vol. 33, pp. 206-219, 2015.

[86] J. Yang, W. Cao, and Y. Rui, "Interactions between nanoparticles and plants, phytotoxicity and defense mechanisms," Journal of Plant Interactions, vol. 12, pp. 158-169, 2017.

[87] A. Rastogi, M. Zivcak, O. Sytar et al., "Impact of metal and metal oxide nanoparticles on plant, a critical review," Frontiers in Chemistry, vol. 5, p. 78, 2017.

[88] G. Ghodake, Y. D. Seo, D. H. Park, and D. S. Lee, "Phytotoxicity of carbon nanotubes assessed by Brassica juncea and Phaseolus mungo," Journal of Nanoelectronics and Optoelectronics, vol. 5, pp. 157-160, 2010.

[89] A. C. Pandey, S. S. Sharda, and R. S. Yadav, "Application of $\mathrm{ZnO}$ nanoparticles in influencing the growth rate of Cicer arietinum," Journal of Experimental Nanoscience, vol. 5, pp. 488-497, 2010.

[90] P. Mahajan, S. K. Dhoke, and A. S. Khanna, "Effect of nano$\mathrm{ZnO}$ particle suspension on growth of mung (Vigna radiata) and gram (Cicer arietinum) seedlings using plant agar method," Journal of Nanotechnology, vol. 2011, Article ID 696535, 7 pages, 2011.

[91] A. Jaberzadeh, P. Moaveni, H. R. Tohidi Moghadam, and H. Zahedi, "Influence of bulk and nanoparticles titanium foliar application on some agronomic traits, seed gluten and starch contents of wheat subjected to water deficit stress," Notulae Botanicae Horti Agrobotanici Cluj-Napoca, vol. 41, no. 1, pp. 201-207, 2013.

[92] R. Suriyaprabha, G. Karunakaran, R. Yuvakkumar, V. Rajendran, and N. Kannan, "Silica nanoparticles for increased silica availability in maize (Zea mays L) seeds under hydroponic conditions," Current Nanoscience, vol. 8, pp. 902-908, 2012.

[93] H. Feizi, M. Kamali, L. Jafari, and M. P. Rezvani, "Phytotoxicity and stimulatory impacts of nanosized and bulk titanium dioxide on fennel (Foeniculum vulgare Mill)," Chemosphere, vol. 91, no. 4, pp. 506-511, 2013.

[94] J. Li, J. Hu, C. Ma et al., "Uptake, translocation and physiological effects of magnetic iron oxide $\left(\gamma-\mathrm{Fe}_{2} \mathrm{O}_{3}\right)$ nanoparticles in corn (_Zea mays_ L.)," Chemosphere, vol. 159, pp. 326-334, 2016.
[95] P. Yugandhar and N. Savithramma, "Green synthesis of calcium carbonate nanoparticles and their effects on seed germination and seedling growth of Vigna mungo," International Journal of Advanced Research, vol. 1, no. 8, pp. 89-103, 2013.

[96] C. M. Rico, S. Majumdar, M. Duarte-Gardea, J. R. PeraltaVidea, and J. L. Gardea-Torresdey, "Interaction of nanoparticles with edible plants and their possible implications in the food chain," Journal of Agricultural and Food Chemistry, vol. 59, pp. 3485-3498, 2011.

[97] B. S. Sekhon, "Nanotechnology in agri-food production: an overview," Nanotechnology, Science and Applications, vol. 7, pp. 31-53, 2014.

[98] Z. Lei, S. Mingyu, W. Xiao et al., "Antioxidant stress is promoted by nano-anatase in spinach chloroplasts under UV-B radiation," Biological Trace Element Research, vol. 121, pp. 69-79, 2008.

[99] Y. Haichuan, L. Qingju, L. I. Qiang, C. Shanna, and Z. Lijuan, "Inhibitory effects of nano-TiO2 loaded Pd on cyanobacteria growth," Acta Botanica Boreali-Occidentalia Sinica, vol. 25, pp. 1884-1887, 2005.

[100] W. Xuming, G. Fengqing, M. Linglan et al., "Effects of nanoanatase on ribulose-1, 5-bisphosphate carboxylase/oxygenase mRNA expression in spinach," Biological Trace Element Research, vol. 126, pp. 280-289, 2008.

[101] Q. Wang, X. Ma, W. Zhang, H. Pei, and Y. Chen, "The impact of cerium oxide nanoparticles on tomato (Solanum lycopersicum L.) and its implications for food safety," Metallomics, vol. 4, no. 10, pp. 1105-1112, 2012.

[102] K. S. Siddiqi and A. Husen, "Plant response to engineered metal oxide nanoparticles," Nanoscale research letters, vol. 12, pp. 1-8, 2017.

[103] N. Khan and A. Bano, "Exopolysaccharide producing rhizobacteria and their impact on growth and drought tolerance of wheat grown under rainfed conditions," PLoS One, vol. 14, no. 9, article e0222302, 2019.

[104] C. Liu, F. Li, C. Luo et al., "Foliar application of two silica sols reduced cadmium accumulation in rice grains," Journal of Hazardous Materials, vol. 161, pp. 1466-1472, 2009.

[105] J. E. Cañas, M. Long, S. Nations et al., "Effects of functionalized and nonfunctionalized single-walled carbon nanotubes on root elongation of select crop species," Environmental Toxicology and Chemistry, vol. 27, pp. 1922-1931, 2008.

[106] D. K. Tiwari, N. Dasgupta-Schubert, L. V. Cendejas, J. Villegas, L. C. Montoya, and S. B. García, "Interfacing carbon nanotubes (CNT) with plants: enhancement of growth, water and ionic nutrient uptake in maize (Zea mays) and implications for nano-agriculture," Applied Nanoscience, vol. 4, no. 5, pp. 577-591, 2014.

[107] F. Rezaei, P. Moaveni, and H. Mozafari, "Effect of different concentrations and time of nano $\mathrm{TiO} 2$ spraying on quantitative and qualitative yield of soybean (Glycine max L.) at Shahr-e-Qods, Iran,” Biological Forum, vol. 7, pp. 957-964, 2015.

[108] G. Ghodake, Y. D. Seo, and D. S. Lee, "Hazardous phytotoxic nature of cobalt and zinc oxide nanoparticles assessed using Allium cepa," Journal of Hazardous Materials, vol. 186, pp. 952-955, 2011.

[109] H. Mahmoodzadeh, M. Nabavi, and H. Kashefi, "Effect of nanoscale titanium dioxide particles on the germination and growth of canola (Brassica napus)," Journal of Ornamental and Horticultural Plants, vol. 3, pp. 25-32, 2013. 
[110] P. Singh, R. Singh, A. Borthakur et al., "Effect of nanoscale $\mathrm{TiO} 2$-activated carbon composite on Solanum lycopersicum (L.) and Vigna radiata (L.) seeds germination," Energy, Ecology and Environment, vol. 1, no. 3, pp. 131-140, 2016.

[111] S. K. Dhoke, P. Mahajan, R. Kamble, and A. Khanna, "Effect of nanoparticles suspension on the growth of mung (Vigna radiata) seedlings by foliar spray method," Nanotechnology Development, vol. 3, no. 1, article e1, 2013.

[112] T. Y. Kuang, Ed., Mechanism and Regulation of Primary Energy Conversion Process in Photosynthesis, Science and Technology Press, Jiangsu, Nanjing, 2003.

[113] Z. Lei, S. Mingyu, L. Chao et al., "Effects of nanoanatase TiO2 on photosynthesis of spinach chloroplasts under different light illumination," Biological Trace Element Research, vol. 119, pp. 68-76, 2007.

[114] R. Raliya, J. C. Tarafdar, and P. Biswas, "Enhancing the mobilization of native phosphorus in the mung bean rhizosphere using $\mathrm{ZnO}$ nanoparticles synthesized by soil fungi," Journal of Agricultural and Food Chemistry, vol. 64, no. 16, pp. 3111-3118, 2016.

[115] Y. Ze, C. Liu, L. Wang, M. Hong, and F. Hong, "The regulation of $\mathrm{TiO} 2$ nanoparticles on the expression of lightharvesting complex II and photosynthesis of chloroplasts of Arabidopsis thaliana," Biological Trace Element Research, vol. 143, pp. 1131-1141, 2011.

[116] A. Singh, S. M. Prasad, and S. Singh, "Impact of nano $\mathrm{ZnO}$ on metabolic attributes and fluorescence kinetics of rice seedlings," Environmental Nanotechnology, Monitoring \& Management, vol. 9, pp. 42-49, 2018.

[117] S. Pradhan, P. Patra, S. Das et al., "Photochemical modulation of biosafe manganese nanoparticles on Vigna radiata, a detailed molecular, biochemical, and biophysical study," Environmental Science \& Technology, vol. 47, pp. 1312213131, 2013.

[118] M. Delfani, M. B. Firouzabadi, N. Farrokhi, and H. Makarian, "Some physiological responses of black-eyed pea to iron and magnesium nanofertilizers," Communications in soil science and plant analysis, vol. 45, no. 4, pp. 530-540, 2014.

[119] J. P. Giraldo, M. P. Landry, S. M. Faltermeier et al., "Plant nanobionics approach to augment photosynthesis and biochemical sensing," Nature Materials, vol. 13, pp. 400-408, 2014.

[120] M. H. Siddiqui and M. H. Al-Whaibi, "Role of nano-SiO2 in germination of tomato (Lycopersicum esculentum seeds Mill.)," Saudi journal of biological sciences, vol. 21, pp. 1317, 2014.

[121] M. Faizan, A. Faraz, M. Yusuf, S. T. Khan, and S. Hayat, "Zinc oxide nanoparticle-mediated changes in photosynthetic efficiency and antioxidant system of tomato plants," Photosynthetica, vol. 56, pp. 678-686, 2017.

[122] F. Q. Gao, F. S. Hong, C. Liu et al., "Mechanism of nanoanatase $\mathrm{TiO} 2$ on promoting photosynthetic carbon reaction of spinach, inducing complex of rubiscoe rubisco activase," Biological Trace Element Research, vol. 111, pp. 239-253, 2006.

[123] H. S. Jiang, L. Y. Yin, N. N. Ren et al., "Silver nanoparticles induced reactive oxygen species via photosynthetic energy transport imbalance in an aquatic plant," Nanotoxicology, vol. 11, pp. 157-167, 2017.

[124] S. Rawat, V. L. Pullagurala, M. Hernandez-Molina et al., "Impacts of copper oxide nanoparticles on bell pepper (Capsicum annum L.) plants: a full life cycle study," Environmental Science: Nano, vol. 5, pp. 83-95, 2018.
[125] F. K. Choudhury, R. M. Rivero, E. Blumwald, and R. Mittler, "Reactive oxygen species, abiotic stress and stress combination," The Plant Journal, vol. 90, no. 5, pp. 856-867, 2017.

[126] Z. Zhang, S. Ali, T. Zhang, W. Wang, and L. Xie, "Identification, evolutionary and expression analysis of PYL-PP2CSnRK2s gene families in soybean," Plants, vol. 9, no. 10, p. 1356, 2020.

[127] G. Onaga and W. Kerstin, "Advances in plant tolerance to biotic stresses," in Plant Genomics, I. Y. Abdurakhmonov, Ed., pp. 167-228, InTech, Rijeka, Croatia, 2016.

[128] A. Y. Mushtaq, S. A. Rizwan, N. E. Jamil et al., "Influence of silicon sources and controlled release fertilizer on the growth of wheat cultivars of Balochistan under salt stress," Pakistan Journal of Botany, vol. 51, no. 5, pp. 1561-1567, 2019.

[129] M. H. Gowayed, H. S. Al-Zahrani, and E. M. Metwali, "Improving the salinity tolerance in potato (Solanum tuberosum) by exogenous application of silicon dioxide nanoparticles," International Journal of Agriculture and Biology, vol. 19, no. 1, 2017.

[130] S. L. Laware and S. Raskar, "Effect of titanium dioxide nanoparticles on hydrolytic and antioxidant enzymes during seed germination in onion," International Journal of Current Microbiology and Applied Sciences, vol. 3, no. 7, pp. 749-760, 2014.

[131] N. Khan and A. Bano, "Effects of exogenously applied salicylic acid and putrescine alone and in combination with rhizobacteria on the phytoremediation of heavy metals and chickpea growth in sandy soil," International journal of phytoremediation, vol. 20, no. 5, pp. 405-414, 2018.

[132] Z. F. Pei, D. F. Ming, D. Liu et al., "Silicon improves the tolerance to water-deficit stress induced by polyethylene glycol in wheat (Triticum aestivum L.) seedlings," Plant Growth Regulation, vol. 29, no. 1, pp. 106-115, 2010.

[133] Z. Iqbal, A. Sarkhosh, R. Balal et al., "Silicon alleviate hypoxia stress by improving enzymatic and non-enzymatic antioxidants and regulating nutrient uptake in muscadine grape (Muscadinia rotundifolia Michx.)," Frontiers in Plant Science, vol. 11, 2020.

[134] T. Elsakhawy, A. E. D. Omara, T. Alshaal, and H. El-Ramady, "Nanomaterials and plant abiotic stress in agroecosystems," Environment, Biodiversity and Soil Security, vol. 2, no. 2018, pp. 73-94, 2018.

[135] S. D. Gupta, A. Agarwal, and S. Pradhan, "Phytostimulatory effect of silver nanoparticles (AgNPs) on rice seedling growth: an insight from antioxidative enzyme activities and gene expression patterns," Ecotoxicology and Environmental Safety, vol. 161, pp. 624-633, 2018.

[136] C. L. Zhang, H. S. Jiang, S. P. Gu et al., "Combination analysis of the physiology and transcriptome provides insights into the mechanism of silver nanoparticles phytotoxicity," Environmental Pollution, vol. 252, no. Part B, pp. 1539-1549, 2019.

[137] F. Zulfiqar, M. Navarro, M. Ashraf, N. A. Akram, and S. Munné-Bosch, "Nanofertilizer use for sustainable agriculture: advantages and limitations," Plant Science, vol. 289, p. 110270, 2019.

[138] G. L. Vanti, V. B. Nargund, R. Vanarchi et al., "Synthesis of Gossypium hirsutum-derived silver nanoparticles and their antibacterial efficacy against plant pathogens," Applied Organometallic Chemistry, vol. 33, no. 1, article e4630, 2019.

[139] J. J. G. Guerrero, P. Songkumarn, T. U. Dalisay, I. B. Pangga, and N. D. Organo, "Toxicity of $\mathrm{CuO}$ and $\mathrm{ZnO}$ nanoparticles 
and their bulk counterparts on selected soil-borne fungi," Agriculture and Natural Resources, vol. 54, no. 3, pp. 325332, 2020.

[140] J. Chen, L. Wu, M. Lu, S. Lu, Z. Li, and W. Ding, "Comparative study on the fungicidal activity of metallic $\mathrm{MgO}$ nanoparticles and macroscale $\mathrm{MgO}$ against soilborne fungal phytopathogens," Frontiers in Microbiology, vol. 11, p. 365, 2020.

[141] L. Cai, J. Chen, Z. Liu, H. Wang, H. Yang, and W. Ding, "Magnesium oxide nanoparticles: effective agricultural antibacterial agent against Ralstonia solanacearum," Frontiers in Microbiology, vol. 9, p. 790, 2018.

[142] M. R. Khan, F. Ahamad, and T. F. Rizvi, "Effect of nanoparticles on plant pathogens," in Advances in Phytonanotechnology, pp. 215-240, Academic Press, 2019.

[143] R. Mohammadi, R. Maali-Amiri, and A. Abbasi, "Effect of TiO2 nanoparticles on chickpea response to cold stress," Biological Trace Element Research, vol. 152, pp. 403-410, 2013.

[144] H. Hasanpour, R. Maali-Amiri, and H. Zeinali, "Effect of $\mathrm{TiO} 2$ nanoparticles on metabolic limitations to photosynthesis under cold in chickpea," Russian Journal of Plant Physiology, vol. 62, pp. 779-787, 2015.

[145] R. Mohammadi, R. MaaliAmiri, and N. Mantri, "Effect of $\mathrm{TiO} 2$ nanoparticles on oxidative damage and antioxidant defense systems in chickpea seedlings during cold stress," Russian Journal of Plant Physiology, vol. 61, no. 6, pp. 768775, 2014.

[146] J. Xu, J. Yang, X. Duan, Y. Jiang, and P. Zhang, "Increased expression of native cytosolic $\mathrm{Cu} / \mathrm{Zn}$ superoxide dismutase and ascorbate peroxidase improves tolerance to oxidative and chilling stresses in cassava (Manihot esculenta Crantz)," BMC Plant Biology, vol. 14, no. 1, p. 208, 2014.

[147] M. Haghighi, R. Abolghasemi, and J. A. Teixeira da Silva, "Low and high temperature stress affect the growth characteristics of tomato in hydroponic culture with Se and nano-Se amendment," Scientia Horticulturae, vol. 178, pp. 231-240, 2014.

[148] M. Hasanuzzaman, K. Nahar, and M. Fujita, "Silicon and selenium: two vital trace elements that confer abiotic stress tolerance to plants," in Emerging Technologies and Management of Crop Stress Tolerance, pp. 377-422, Elsevier, The Netherlands, 2014.

[149] A. Wahid, "Physiological implications of metabolites biosynthesis in net assimilation and heat stress tolerance of sugarcane (Saccharum officinarum) sprouts," Journal of Plant Research, vol. 120, pp. 219-228, 2007.

[150] M. V. Khodakovskaya, K. de Silva, D. A. Nedosekin et al., "Complex genetic, photothermal, and photoacoustic analysis of nanoparticle-plant interactions," Proceedings of the National Academy of Sciences of the United States of America, vol. 108, no. 3, pp. 1028-1033, 2011.

[151] S. Ali, K. Hayat, A. Iqbal, and L. Xie, "Implications of abscisic acid in the drought stress tolerance of plants," Agronomy, vol. 10, no. 9, p. 1323, 2020.

[152] M. I. R. Khan, S. Syeed, R. Nazar, and N. A. Anjum, “An insight into the role of salicylic acid and jasmonic acid in salt stress tolerance," in Phytohormones and Abiotic Stress Tolerance in Plants, N. A. Khan, R. Nazar, N. Iqbal, and N. A. Anjum, Eds., pp. 277-300, Springer Verlag, 2012.

[153] M. N. Khan, M. H. Siddiqui, F. Mohammad, and M. Naeem, "Interactive role of nitric oxide and calcium chloride in enhancing tolerance to salt stress," Nitric Oxide, vol. 27, no. 4, pp. 210-218, 2012.

[154] S. U. Jalil and M. I. Ansari, "Nanoparticles and abiotic stress tolerance in plants: synthesis, action, and signaling mechanisms," in Plant Signaling Molecules, pp. 549-561, Woodhead Publishing, 2019.

[155] F. Mirzajani, H. Askari, S. Hamzelou et al., "Proteomics study of silver nanoparticles toxicity on Oryza sativa L.," Ecotoxicology and Environmental Safety, vol. 108, pp. 335-339, 2014.

[156] M. R. Maghsoodi, L. Ghodszad, and B. A. Lajayer, "Dilemma of hydroxyapatite nanoparticles as phosphorus fertilizer: potentials, challenges and effects on plants," Environmental Technology \& Innovation, vol. 19, article 100869, 2020.

[157] M. Boudsocq and J. Sheen, "CDPKs in immune and stress signaling," Trends in Plant Science, vol. 18, no. 1, pp. 30-40, 2013.

[158] Z. M. Almutairi, "Effect of nano-silicon application on the expression of salt tolerance genes in germinating tomato (Solanum lycopersicum L.) seedlings under salt stress," Plant Omics, vol. 9, pp. 106-114, 2016.

[159] J. H. Kim, Y. Oh, H. Yoon, I. Hwang, and Y.-S. Chang, "Iron nanoparticle-induced activation of plasma membrane $\mathrm{Hp}$ ATPase promotes stomatal opening in Arabidopsis thaliana," Environmental Science \& Technology, vol. 49, pp. 1113-1119, 2015.

[160] R. Kaveh, Y. S. Li, S. Ranjbar, R. Tehrani, C. L. Brueck, and B. Van Aken, "Changes in Arabidopsis thaliana gene expression in response to silver nanoparticles and silver ions," Environmental Science \& Technology, vol. 47, no. 18, pp. 10637-10644, 2013.

[161] P. Landa, R. Vankova, J. Andrlova et al., "Nanoparticle-specific changes in Arabidopsis thaliana gene expression after exposure to $\mathrm{ZnO}, \mathrm{TiO} 2$, and fullerene soot," Journal of Hazardous Materials, vol. 241, pp. 55-62, 2012.

[162] T. P. Frazier, C. E. Burklew, and B. Zhang, "Titanium dioxide nanoparticles affect the growth and microRNA expression of tobacco (Nicotiana tabacum)," Functional \& integrative genomics, vol. 14, no. 1, pp. 75-83, 2014.

[163] S. Singh, K. Vishwakarma, S. Singh et al., "Understanding the plant and nanoparticle interface at transcriptomic and proteomic level: a concentric overview," Plant Gene, vol. 11, pp. 265-272, 2017.

[164] G. Mustafa and S. Komatsu, "Nanoparticles mediated soybean response mechanism at morphological, physiological, and proteomic level," Current Proteomics, vol. 14, no. 1, pp. 3-12, 2017.

[165] S. Asad and M. Arsh, "Silicon carbide whisker-mediated plant transformation," in Properties and Applications of Silicon Carbide, R. Gerhardt, Ed., pp. 1-16, BoD-Books on Deman, Rijeka, 2012.

[166] H. Y. Lau, H. Wu, E. J. H. Wee, M. Trau, Y. Wang, and J. R. Botella, "Specific and sensitive isothermal electrochemical biosensor for plant pathogen DNA detection with colloidal gold nanoparticles as probes," Scientific Reports, vol. 7, p. 38896, 2017.

[167] N. Mitter, E. A. Worrall, K. E. Robinson et al., "Clay nanosheets for topical delivery of RNAi for sustained protection against plant viruses," Nature plants, vol. 3, p. 16207, 2017.

[168] X. Zhao, Z. Meng, Y. Wang et al., "Pollen magnetofection for genetic modification with magnetic nanoparticles as gene carriers," Nature Plants, vol. 3, no. 12, pp. 956-964, 2017. 
[169] G. S. Demirer, H. Zhang, J. L. Matos et al., "High aspect ratio nanomaterials enable delivery of functional genetic material without DNA integration in mature plants," bioRxiv, vol. 10, pp. 1-32, 2018.

[170] S. Martin-Ortigosa, D. J. Peterson, J. S. Valenstein et al., "Mesoporous silica nanoparticle-mediated intracellular Cre protein delivery for maize genome editing via loxP site excision," Plant Physiology, vol. 164, pp. 537-547, 2013. 